Cahiers $d u$ MONDE RUSSE

\section{Cahiers du monde russe}

Russie - Empire russe - Union soviétique et États indépendants

Les pratiques administratives en Union soviétique, 1920-1960

\title{
Repressii v apparate MGB v poslednie gody zizni Stalina, 1951-1953.
}

\section{Nikita PETROV}

\section{Q OpenEdition}

\section{Journals}

Édition électronique

URL : https://journals.openedition.org/monderusse/8616

DOI : 10.4000/monderusse.8616

ISSN : $1777-5388$

Éditeur

Éditions de l'EHESS

\section{Édition imprimée}

Date de publication : 1 avril 2003

Pagination : 403-436

ISBN : 2-7132-1813-6

ISSN : $1252-6576$

Référence électronique

Nikita PETROV, "Repressii v apparate MGB v poslednie gody zizni Stalina, 1951-1953. », Cahiers du monde russe [En ligne], 44/2-3 | 2003, mis en ligne le 01 janvier 2007, consulté le 04 septembre 2022 URL : http://journals.openedition.org/monderusse/8616; DOI : https://doi.org/10.4000/monderusse. 8616 


\section{CAIR N}

chercher : repérer : avancer

Cet article est disponible en ligne à l'adresse :

http://www.cairn.info/article.php?ID REVUE=CMR\&ID NUMPUBLIE=CMR 442\&ID ARTICLE=CMR 4420403

Repressii v apparate MGB v poslednie gody zizni Stalina, 1951-1953

par Nikita PETROV

| Editions de l'EHESS | Cahiers du monde russe

2003/2-3 Vol 44

ISSN 1252-6576 | ISBN 2713218136 | pages 403 à 436

Pour citer cet article :

- PETROV N., Repressii v apparate MGB v poslednie gody zizni Stalina, 1951-1953, Cahiers du monde russe 2003/2, Vol 44, p. 403-436.

Distribution électronique Cairn pour les Editions de l'EHESS.

(C) Editions de l'EHESS. Tous droits réservés pour tous pays.

La reproduction ou représentation de cet article, notamment par photocopie, n'est autorisée que dans les limites des conditions générales d'utilisation du site ou, le cas échéant, des conditions générales de la licence souscrite par votre établissement. Toute autre reproduction ou représentation, en tout ou partie, sous quelque forme et de quelque manière que ce soit, est interdite sauf accord préalable et écrit de l'éditeur, en dehors des cas prévus par la législation en vigueur en France. Il est précisé que son stockage dans une base de données est également interdit. 


\title{
НИКИТА ПЕТРОВ
}

\section{РЕПРЕССИИ В АППАРАТЕ МГБ В ПОСЛЕДНИЕ ГОДЫ ЖИЗНИ СТАЛИНА 1951-1953}

\author{
«Я не проситель у МГБ. Я могу и потребовать, \\ и в морду дать, если вами не будут выполняться \\ мои требования» \\ «Мы вас разгоним как баранов» \\ И. Сталин, октябрь 1951 - январь 1952.
}

В начале 50-х годов произошли многочисленные аресты среди руководящих работников министерства государственной безопасности (МГБ) СССР. Как и в 1937 г. руководителям этого карательного ведомства вновь было отказано в сталинском доверии, и после ареста в июле 1951 г. министра В. С. Абакумова, никто из верхушки МГБ уже не мог быть уверен, что он не станет следующей жертвой. В чем была причина очередной чистки аппарата госбезопасности и какие обвинения были предъявлены арестованным чекистам? Каковы были конечные цели Сталина в отношении МГБ, и, наконец, означало ли все это подготовку нового витка массового террора против населения, по примеру предвоенных лет? В последнее время опубликовано несколько научных и публицистических работ, в которых делаются попытки ответить на эти вопросы ${ }^{1}$. Большинство авторов сходятся во мнении, что периодически устраиваемые Сталиным чистки аппарата госбезопасности и реорганизации его структуры, сопровождаемые вливанием

\footnotetext{
1. Приведем лишь несколько, наиболее заметных: Michael Parrish, The lesser terror: Soviet state security, 1939-1953, Westport, CO - London, 1996, p. 229-253; K. A. Столяров, Палачи и жертвы, М., 1998; Р. Г. Пихоя, Советский Союз: история власти, 1945-1991, Новосибирск, 2000, с. 61-79; Г. В. Костырченко, Тайная политика Сталина, М., 2001, с. 455-474; O. Hlevnjuk [Хлевнюк], «Сталин и органы государственной безопасности в послевоенный период», Cahiers du Monde russe, 42/2-34, avril-décembre 2001, p. 535-547.
} 
свежих партийных кадров и арестами засидевшихся на своих местах руководящих чекистов, были, прежде всего, методом контроля над карательным аппаратом. Также не вызывает сомнений национальный аспект затеянной Сталиным кадровой перетряски (из МГБ поголовно изгонялись евреи). В отношении же конечных целей последних сталинских репрессивных кампаний у историков нет единого мнения. В некоторых работах под сомнение ставится тезис, будто начатая Сталиным чистка МГБ свидетельствует о том, «что страна стояла накануне новой волны массового террора»². Другие авторы утверждают, что в политике Сталина продолжались политические традиции 20-30-х гг.3.

Вместе с тем, до сих пор историками не было сделано попыток детально разобраться - сколько всего чекистов было арестовано в ходе чистки МГБ в 1951-1953 гг. и выявить их основные группы и различия в мотивах их арестов. И хотя большинство было арестовано по обвинению в принадлежности к группе Абакумова, существовали их различные потоки и ответвления следствия. Не все арестованные в это время чекисты прошли по делу «сионистского заговора в МГБ». Разобраться в этом невозможно без привлечения архивных источников, включая материалы следствия. Этот пласт документов в силу своей недоступности (он до сих пор находится на ведомственном хранении в архиве ФСБ) практически не использовался историками ${ }^{4}$. В связи с этим необходимо попытаться взглянуть на происходившие события как бы изнутри, используя материалы следствия (протоколы допросов, заявления арестованных в «инстанции») по делам руководителей органов госбезопасности. Протоколы допросов позволяют, прежде всего, четко проследить хронологию арестов, первоначальные обвинения и их развитие и трансформацию в дальнейшем и, наконец, отражают неформальное положение того или иного функционера в иерархии МГБ, его дружеские связи в чекистской среде. Эти материалы дают возможность понять мотивацию того или иного ареста. В ходе расследования так называемого «заговора в МГБ» протоколы допросов его участников регулярно направлялись новым министром госбезопасности С. Д. Игнатьевым Сталину. Следствие вызывало самый живой интерес вождя. Он лично знакомился с этими бумагами и высказывал свои замечания по проектам обвинительного заключения по делу МГБ в январе и феврале 1953 г. Нет нужды говорить, что привлечение в качестве источника

\footnotetext{
2. О. Хлевнюк, указ. соч., р. 547.

3. Р. Г. Пихоя, указ. соч., с. 78 .

4. Исключение составляют публицистические работы журналиста К. Столярова, который получил доступ к материалам следствия по делу Абакумова и некоторых других высокопоставленных чекистов бериевского круга. В целом для работ Столярова характерно полное отсутствие архивных отсылок и некритическое отношение к материалам следствия (протоколам допросов, заявлениям арестованных) - весьма специфическому материалу. Видимо, последнее обстоятельство, объясняется явными симпатиями и сочувствием к Абакумову, чью судьбу он оплакивает. (К. А. Столяров, Голгофа, М., 1991).
} 
материалов такого уровня позволяет составить более или менее полную картину событий.

\section{1. «Дело Абакумова»}

Аппарат госбезопасности занимал особое и привилегированное положение в сталинской системе власти. Руководителей МГБ Сталин назначал сам, не нуждаясь ни в чьих советах. Так, 4 мая 1946 г. вместо В. Н. Меркулова, который по мнению Сталина был слишком робок и нерешителен, на должность министра госбезопасности (далее по тексту ГБ) был назначен В. С. Абакумов. Вместе с тем, в послевоенные годы повседневное руководство работой МГБ, а также выдвижение и распределение кадров этой карательной структуры Сталин передоверил сначала своему заместителю по Совету министров - Л. П. Берии 5 , а затем с 17 сентября 1947 г. Секретарю ЦК ВКП(б) А. А. Кузнецову 6 . При этом решение важнейших вопросов, таких как выработка репрессивной линии, реорганизация структуры МГБ, согласование важнейших арестов, оставалось по-прежнему за Сталиным. Он лично давал указания о проведении тех или иных репрессивных кампаний и первый знакомился с результатами деятельности МГБ. В ежедневном потоке бумаг, которыми знакомился стареющий диктатор, по-прежнему, как и в 30-е годы, огромную часть составляли протоколы допросов «государственных преступников», арестованных органами госбезопасности.

После возникновения «Ленинградского дела» и ареста в 1949 г. бывшего Секретаря ЦК ВКП(б) Кузнецова тень сталинского недоверия легла и на Абакумова. И это неслучайно, ведь Абакумов имел довольно тесные отношения со своим бывшим куратором. Причем настолько, что ряд текущих вопросов предпочитал решать на уровне Кузнецова, не доводя их до Сталина ${ }^{7}$. Трудно сказать, тогда ли у Сталина возникла мысль избавиться от министра ГБ, но, по крайней мере, иезуитский расчет вождя состоял в том, что именно Абакумов должен обеспечить проведение «Ленинградского дела», по которому в числе прочих проходил Кузнецов. А уж потом, когда нужда в Абакумове отпадет - избавиться от него. Есть явные признаки, свидетельствующие о потери Абакумовым доверия Сталина. Так, в феврале 1950 г. он поручил Г. М. Маленкову организовать «особую тюрьму» для «самых важных политических обвиняемых», которая находилась бы в

5. См.: Постановление СМ СССР № 674 от 28 марта 1946 г. (Политбюро ЦК ВКП(б) и Совет Министров СССР. 1945-1953 г2., М., 2002, с. 30).

6. Там же, с. 51. А. А. Кузнецов после Г. М. Маленкова возглавлял Управление кадров ЦК ВКП(б) с 13.04.46 по 10.07.48.

7. В начале 1948 г. на это обратил внимание Сталин, когда без согласования с ним Кузнецов разрешил Абакумову предать «суду чести» в МГБ двух проштрафившихся офицеров. По инициативе разгневанного Сталина Политбюро 15 марта 1948 г. вынесло взыскание Абакумову за его действия «без ведома и согласия Политбюро» и Кузнецову за «единоличное согласие на организацию суда». (О. Хлевнюк, указ. соч., р. 538). 
подчинении Комитета партийного контроля при ЦК ВКП(б) следователи МГБ, а сотрудники партийного аппарата сами вели следствие по делам этих арестованных. Весной 1950 г. Сталин неожиданно высказывал Абакумову свои соображения о необходимости ареста начальника отдела «ДР» (диверсионной и террористической работы) МГБ генерал-лейтенанта П. А. Судоплатова, его заместителя генерал-майора Н. И. Эйтингона и ряда других ответственных работников МГБ. Абакумов, к неудовольствию вождя, не только проявил нерешительность в этом вопросе, но, хуже того, поделился своими сомнениями с Берией. Позднее, Берия будучи уже арестованным, сам рассказал об этом эпизоде, проливающем дополнительный свет на предысторию арестов в МГБ:

[...] в 1950 году в середине или в начале года Абакумов, будучи у меня в Совете Министров по другим вопросам, рассказал, что он имеет указание И. В. Сталина арестовать Судоплатова, Эйтингона и ряд других сотрудников. Абакумов не сказал мне за что их надо арестовать. Для меня было ясно, что арест Судоплатова означал его уничтожение. Поэтому я сказал Абакумову, чтобы он еще раз поговорил со Сталиным, тем более, что причин ареста Судоплатова Абакумов не назвал. Я сказал Абакумову: «Я бы на твоем месте сохранил Судоплатова и не дал бы уничтожить.»9

Другой демарш Сталина против Абакумова и его всевластия в аппарате МГБ лежал в организационной плоскости. В январе 1950 г. Сталин решил создать в МГБ Коллегию и дал соответствующее указание Абакумову ${ }^{10}$. По замыслу Сталина этот коллегиальный орган управления Министерством усилил бы контроль за деятельностью Абакумова и помог бы растворить его амбиции. Решение о создании Коллегии МГБ было принято 31 декабря 1950 г. после возвращения Сталина из очередного длительного осеннего отпуска (с 11 августа по 21 декабря 1950 г.) $)^{11}$. Приехав в Москву, Сталин резко сократил

8. Р. Г. Пихоя, указ. соч., с. 63.

9. Этот эпизод вошел в подготовленное в 1954 г. обвинительное заключение по делу Абакумова (ЦА ФСБ, ф. 5-ос., оп. 1, д. 13, л. 214). См. также: АП РФ, ф. 3, оп. 24, д. 466 , л. 156

10. Первоначальные предложения были подготовлены В. С. Абакумовым и С. И. Огольцовым еще 31 января 1950 г. и направлены письмом Сталину. В нем, в частности содержалось предложение направить в МГБ «одного, двух крупных партийных работников, имея ввиду, чтобы они были также членами Коллегии МГБ СССР». За предыдущие 3 года, писалось далее, в МГБ было направлено 540 партийно-советских работников, но при этом «среди них нет работников крупного масштаба с широким кругозором, которых можно было бы иметь в числе членов Коллегии МГБ СССР» (АП РФ, ф. 45, оп. 1 , д. 183 , л. 61-70).

11. Второй вариант (и окончательный) письма Абакумова Сталину о создании Коллегии МГБ СССР, увеличении числа заместителей министра до 7 человек и кадровых перемещениях руководящего состава был подготовлен 2 августа 1950 г. К нему был приложен и проект решения Политбюро ЦК (ЦА ФСБ, ф. 4-ос., оп. 8, д. 8, л. 40-48). Сталин просто не успел его рассмотреть до отъезда. Проволочка в принятии решения вряд ли связана с решением Сталина дождаться окончания «Ленинградского дела", как об этом иногда пишут (См. О. Хлевнюк, указ. соч., с. 540.). Текст принятого решения политбюро об образовании Коллегии МГБ СССР См.: Политбюро ЦК 
контакты с Абакумовым, пригласив его в свой кремлевский кабинет только один раз - 6 апреля 1951 г. ${ }^{12}$. Трудно сказать, понял ли Абакумов, сколь серьезен этот знак и что против него что-то затевается. После этого в журнале посетителей кремлевского кабинета Сталина фамилия Абакумова встретится только 5 июля 1951 г., когда уже было принято решение снять его с должности министра.

Начало кампании кадровой чистки системы МГБ, сопровождавшейся арестами высокопоставленных сотрудников, было положено специальным решением Сталина и Политбюро ЦК ВКП(б) после рассмотрения заявления М. Д. Рюмина - старшего следователя следственной части по особо важным делам (ОВД) МГБ СССР. Вернее будет сказать, что заявление Рюмина было скорее поводом, ибо мысль о проведении чистки и арестов в МГБ, как показано выше, зрела у Сталина давно. После того, как Сталин получил в руки заявление Рюмина, настала пора действовать ${ }^{13}$. Что же писал этот следователь? В письме Рюмина, датированном 2 июля 1951 г., содержался ряд обвинений против Абакумова. Во-первых, он «погасил», очень перспективное, с точки зрения автора письма, дело арестованного МГБ врача Я.Г. Этингера, который мог дать важные показания о «врачахвредителях». Во-вторых, Абакумов скрыл от ЦК важную информацию о недостатках в контрразведывательной работе в Германии на предприятиях «Висмута», где добывалась урановая руда. И, наконец, в третьих, грубо нарушал установленные решениями партии и правительства правила ведения следствия. В письме Рюмин назвал Абакумова «опасным человеком» на важном государственном посту ${ }^{14}$.

По заявлению Рюмина 5 июля 1951 г. ${ }^{15}$ Политбюро ЦК ВКП(б) приняло следующее решение (П82/404):

ВКП(б)..., указ. соч., с. 342-343. Хотя в этой книге по ошибке оно датировано 3 декабря (в действительности - 31 декабря 1950 г.)

12. Исторический архив, № 4, 1998, с. 16.

13. Существует версия, что письмо Рюмина попало в руки Сталина не без помощи Г. М. Маленкова и его помощника Д. Н. Суханова (Г. В. Костырченко, Тайная политика..., указ. соч., с. 455-456).

14. АП РФ, ф. 3. оп. 58 , д. 10.

15. В ночь с 5 на 6 июля 1951 г. Сталиным в Кремле были принят Рюмин. Из МГБ присутствовали Абакумов и его первый заместитель С. И. Огольцов. При этом присутствовали Молотов, Булганин, Берия и Маленков. Сталин точно продумал сценарий встречи. Сначала, в присутствии других членов Политбюро в кабинет ровно в час ночи был приглашен Абакумов, и лишь после того, как Сталин имел возможность выяснить у него все интересующие вопросы, в 1 час 40 минут в кабинет позвали Рюмина (очень похоже на очную ставку). А Огольцова пригласили лишь за пять минут до конца аудиенции. Вероятнее всего, для того чтобы возложить на него временное исполнение обязанностей министра ГБ. (См.: Исторический архив, № 1, 1997, с. 24) 
Поручить комиссии в составе т.т. Маленкова (председатель), Берия, Шкирятова и Игнатьева проверить факты изложенные в заявлении Рюмина, и доложить о результатах Политбюро ЦК ВКП(б). Срок работы комиссии 3-4 дня ${ }^{16}$.

Абакумов еще не был арестован, но уже 8 июля 1951 г. побывал на допросе у исполняющего обязанности Генерального прокурора К. А. Мокичева. Накануне, 7 июля Абакумов написал объяснительную записку по выдвинутым против него обвинениям. В записке рассказывалось об обстоятельствах дела Этингера. В ноябре 1950 г. Абакумов направил Сталину в Сочи записку с просьбой дать санкцию на арест Этингера. Поскребышев переадресовал Абакумова к Булганину, который и дал санкцию. Этингер был арестован 18 ноября 1950 г. и, по уверениям Абакумова, никаких существенных показаний не давал, у него были частые сердечные припадки и, в конце концов, в результате допросов проводимых Рюминым, он умер. Все обвинения Рюмина в связи с делом Этингера Абакумов отметал, заверяя в этой объяснительной записке Сталина в своей личной преданности ${ }^{17}$. Тем не менее, 12 июля 1951 г. Абакумов был арестован и доставлен в «особую тюрьму» ${ }^{18}$. Следствие по его делу было поручено вести Прокуратуре СССР.

11 июля Политбюро ЦК ВКП(б) принимает специальное решение (П82/437) «о неблагополучном положении в МГБ», в котором повторены все обвинения Рюмина в адрес Абакумова и добавлены новые, например: «обман партии», затягивание следственных дел. Текст постановления «закрытым письмом» был разослан для ознакомления руководителям партийных органов и органов МГБ ${ }^{19}$. Следом за Абакумовым 13 июля были арестованы начальник следственной части МГБ А. Г. Леонов и его заместители М. Т. Лихачев и Л. Л. Шварцман. Чуть позже, 25 июля 1951 г. был арестован управляющий делами МГБ М. К. Кочегаров, а 26 июля 1951 г. арестовали еще одного заместителя начальника следственной части МГБ В.И. Комарова. После этого аресты руководящих работников МГБ приобрели более или менее регулярный характер.

После смещения Абакумова исполнять обязанности министра стал С. И. Огольцов. Но 3 августа 1951 г. он направил Сталину сообщение, что болен и по заключению врачей ему прописан постельный режим. Огольцов предложил временно возложить исполнение обязанностей министра госбезопасности на Е. П. Питовранова и на него же «возложить участие в

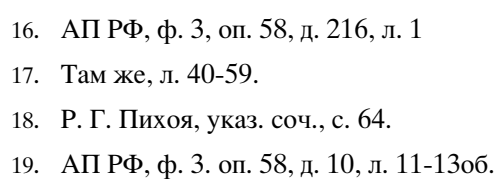


допросах по делу Абакумова» ${ }^{20}$. Так и случилось. Вплоть до назначения Игнатьева министром, все докладные записки из МГБ на имя Сталина подписывал Питовранов.

Незадолго до отпуска Сталин 24 июля 1951 г. провел одну важную встречу с руководителями МГБ в присутствии Л. П. Берии и Г. М. Маленкова, на которой дал указания о серьезной перестройке агентурнооперативной работы, предложив сократить тайную сеть МГБ на 2/3 (оставив только часть агентов и сократив всех осведомителей). Накануне своего отъезда Сталин, 9 августа 1951 г., назначил министром ГБ партийного аппаратчика С. Д. Игнатьева, демонстративно оставив его по совместительству в должности заведующего Отделом партийных, профсоюзных и комсомольских органов ЦК ВКП(б). В том же месяце был пересмотрен состав заместителей министра ГБ. Вместо партийного выдвиженца В. Е. Макарова, призванного 31 декабря 1950 г. проводить партийную линию и контролировать кадровую работу в МГБ, заместителем министра ГБ по кадрам был назначен А. А. Епишев, ранее работавший первым секретарем Одесского обкома партии, затем инспектором ЦК ВКП(б). Помимо этого еще два штатских работника были назначены заместителями министра ГБ: И. Т. Савченко (инспектор ЦК) и С. В. Евстафеев (заместитель управляющего делами СМ СССР). При этом, ряд заместителей министра госбезопасности из числа профессионалов-чекистов лишились своих постов ${ }^{21}$.

М. Д. Рюмин в награду за разоблачение Абакумова был назначен в июле исполняющим обязанности начальника следственной части по ОВД МГБ СССР и получил звание полковника. Но останавливаться на достигнутом он не желал и, направив Сталину на юг новое разоблачительное письмо, стал инициатором очередной волны арестов в аппарате МГБ.

Примерно в середине октября 1951 г. $^{22}$ министр ГБ С. Д. Игнатьев и его заместитель Н. П. Стаханов выехали для встречи со Сталиным на юг ${ }^{23}$. При встрече Сталин подробно расспрашивал Игнатьева о работе МГБ и, в частности, о том, хорошо ли работают Е. П. Питовранов, Ф. Г. Шубняков и другие высокопоставленные чекисты. Игнатьев ответил, что в настоящий момент «чекисты работают лучше», а те, о ком Сталин спрашивает, «честные люди». Выслушав его Сталин заявил: «Слепой вы человек, ничего не видите что вокруг вас делается» и дал Игнатьеву прочитать письмо

20. Огольцов писал о том, что он болен острым тромбофлебитом и сообщал о решении врачебного консилиума в составе академиков Бакулева и Виноградова и профессора Егорова. См.: ЦА ФСБ, ф. 4-ос., оп. 9, д. 14, л. 50.

21. Политбюро ЦК ВКП(б)..., указ. соч., с. 347.

22. Вероятнее всего этот визит состоялся в один из дней в период с 11 по 15 октября 1951 г.

23. Об этом визите к Сталину написал в своей объяснительной записке в 1953 г. Игнатьев (ЦА ФСБ, ф. 5-ос., оп. 2, д. 31, л. 455-458). 
Рюмина с обвинениями против Питовранова и других ${ }^{24}$. Тут же, по ходу дела, Сталин дал указание «убрать всех евреев» из МГБ. Игнатьев, недоумевая, спросил куда? И тут вождь изрек: «Я не говорю, чтоб вы их выгоняли на улицу. Посадите и пусть сидят», добавив фразу, которой суждено стать крылатой: «У чекиста есть только два пути - на выдвижение или в тюрьму» ${ }^{25}$.

На это же встрече Сталин в категоричной форме потребовал назначить Рюмина не только начальником следственной части, но и заместителем министра ГБ. Игнатьев пробовал возражать, сославшись на то, что начальником следственной части МГБ уже утвержден А. Н. Кидин (работавший первым секретарем Владимирского обкома) ${ }^{26}$, на что Сталин отреагировал довольно резко, заявив: «Я такого не знаю». Разумеется, Сталин прекрасно знал всех первых секретарей обкомов, но кандидатура Кидина его не устраивала. Решение Сталина о начальнике следственной части было неукоснительно выполнено. Постановлением Совета Министров СССР № 4010-1837сс от 19 октября 1951 г. М. Д. Рюмин был утвержден заместителем министра ГБ, членом Коллегии МГБ СССР и начальником следственной части по ОВД МГБ СССР.

Указание Сталина «убрать евреев» из МГБ, по-видимому, не вызвало внутреннего сопротивления Игнатьева и было сразу же проведено в жизнь. 19 октября 1951 г. последовали аресты. Заодно с чекистами 19 октября был арестован как «еврейский националист» и Лев Шейнин - бывший начальник следственного отдела прокуратуры, а на момент ареста - литератор, мастер детективного жанра, член Союза писателей ${ }^{27}$.

24. Отправив письмо Сталину, Рюмин также написал 10 октября 1951 г. Г. М. Маленкову записку, в которой проинформировал его о своем обращении к Сталину и приложил копию этого обращения. В нем говорилось о недостатках в работе 2 главного управления МГБ и о том, что руководящие работники МГБ: Е. П. Питовранов, Ф. Г. Шубняков, Л. Ф. Райхман, Н. Н. Селивановский, А. С. Блинов, В. П. Рогов, И. А. Чернов и другие, многие годы тесно работали с Абакумовым и находились под его враждебным влиянием.

25. ЦА ФСБ, ф. 5-ос., оп. 2, д. 31, л. 455-458.

26. См. решение Политбюро от 6 октября 1951 г. (Политбюро ЦК РКП(б)-ВКП(б). Повестки дня заседаний. 1919-1952: Каталог, т. 3, М., 2001, с. 828) Неизвестно, как бы сложилась судьба А. Н. Кидина после 1953 г., если ему пришлось бы работать на «лубянской кухне» в такой опасной должности. Кидину повезло и он остался до 1955 г. работать первым секретарем Владимирского обкома.

27. Основанием для ареста Шейнина стали показания на него Шварцмана. Ходатайство о прекращении дела на Шейнина было направлено руководством МВД 16 ноября 1953 г. на имя Хрущева и Маленкова. В нем говорилось, что все давшие на Шейнина уличающие показания от них отказались. Правда, в этом письме говорилось о и попытках бериевцев так или иначе использовать Шейнина. «В марте 1953 г. Шейнин вызывался на допрос Кобуловым, который, по словам самого Шейнина, сказал ему, что “эта башка (то есть Шейнин) еще поработает” и в дальнейшем его неоднократно вызывал на допросы Райхман, которому Кобулов поручил перед освобождением Шейнина завербовать его в агентурную сеть.» (ЦА ФСБ, ф. 4-ос., оп. 11, д. 15, л. 6776). 
Уже 24 октября 1951 г. Игнатьев направил Сталину докладную записку о ходе следствия по делам Л. Ф. Райхмана, А. Я. Свердлова, А. М. Палкина ${ }^{28}$, Н. И. Эйтингона, Л. Е. Иткина и Павловского 29 . Через несколько дней был арестован бывший заместитель начальника 1 управления МГБ СССР М. И. Белкин. Оказалось, что помимо национальности были другие причины для его ареста. Позднее, в середине 50-х годов, когда буря кадровых перемещений бушевавшая в стенах МГБ улеглась, арест Белкина во внутренних бумагах объяснялся просто и понятно:

В 1950-51 гг. в бывшее Министерство государственной безопасности СССР поступило два заявления о том, что Белкин является американским шпионом, в связи с чем в конце 1951 г. был арестован и обвинялся в измене Родине ${ }^{30}$.

Действительные причины ареста Белкина изложены в справке, направленной Игнатьевым 25 октября 1951 г. Сталину. Оказалось за Белкиным Михаилом Ильичем (а на самом деле Белкиным Моисеем Эльновичем, как между прочим, сообщал Игнатьев) много чего числилось. Так, работая начальником контрразведки, он создал «черную кассу», занимался спекуляцией, вел себя «недостойно в быту»- встречался с женщинами, которые в свою очередь имели связи с иностранцами, а, кроме того, Белкин и его жена поддерживали знакомство с писателем-драматургом А. А. Соловьевым, который «разрабатывался МГБ», и характеризовался как «резко антисоветски настроенный человек». Но и это еще не все, дальше хуже. Оказывается, из Вены от некоего арестованного хорвата М. Вомачка поступило сообщение о «связях» Белкина с «масонской ложей и иностранными разведками». Далее мимоходом сообщалось о посещении Белкиным ресторанов и связях с иностранцами в далеких 1917-1918 гг,, а также о проводимых им «арестах невинных людей» (уж в этом можно было обвинить любого чекиста) в бытность его службы в особом отделе 1 Конной армии, а потом и на Лубянке. После этого следовал «убойный факт». Сам Ягода подарил Белкину свою фотокарточку с надписью: «Удачливому мушкетеру от восхищенного ценителя». Такая близость Белкина к объявленному «врагом народа» и расстрелянному наркому могла прямо привести его в тюрьму еще в 1937 г. И в довершении сообщалось, что Абакумов об этом знал, но «дал команду» проверку фактов против Белкина не проводить ${ }^{31}$. Направляя Сталину эту справку, Игнатьев писал: «Прошу Вашего согласия на арест Белкина» ${ }^{32}$. Сталин без промедления дал санкцию на арест, и 28 октября 1951 г. Белкин был арестован.

28. Заместитель начальника отдела «Д» полковник А. М. Палкин арестован 19 октября 1951 г. Его успели осудить на Военной Коллегии Верховного Суда СССР 13 октября 1952 г. на 15 лет (за хищения). Освобожден из лагеря досрочно 29 мая 1956 г.

29. ЦА ФСБ, ф. 4-ос., оп. 9, д. 37.

30. АП РФ, ф. 3, оп. 50, д. 183, л. 134.

31. ЦА ФСБ, ф. 4-ос., оп. 9, д. 23, л. 227-229.

32. Там же, л. 226. 
Для ареста других лиц, упомянутых в доносе Рюмина, Игнатьеву потребовалось напоминание вождя. Вскоре с юга пришло указание арестовать заместителя министра ГБ Е. П. Питовранова и с ним ряд других руководителей МГБ. Питовранов был арестован 27 октября. Также в самых последних числах октября - начале ноября 1951г. были арестованы: начальник 1 управления МГБ Г. В. Утехин (29 октября), бывшие заместители министра ГБ Н. Н. Селивановский $(2 \text { ноября })^{33}$ и Н. А. Королев $(4 \text { ноября) })^{34}$, начальник 2 главного управления МГБ Ф. Г. Шубняков. Хотя не все «абакумовцы», упомянутые в письме Рюмина, были арестованы. Например, избежали ареста А. С. Блинов и В. П. Рогов.

Аресты «людей Абакумова» продолжились и потом. Заместитель начальника секретариата МГБ Я. М. Броверман был арестован 13 ноября 1951 г. и примерно тогда же его начальник - И. А. Чернов.

Также продолжались и аресты чекистов - евреев, и 2 ноября был арестован бывший чекист Я. Н. Матусов ${ }^{35}$, а 21 ноября 1951 г. еще один бывший чекист, а на момент ареста - литератор и сценарист И. Б. Маклярский ${ }^{36}$.

Была и другая волна арестов в 1951 г., связанная, преимущественно со случаями коррупции. Так, 20 октября был арестован генерал-лейтенант П. В. Зеленин ${ }^{37}$, за то, что находясь в Германии, занимался личным обогащением. 3 декабря 1951 арестовали генерал-майора Н. М. Карпенко ${ }^{38}$ - его также обвинили в том, что

[...] работая в 1945 г. начальником отдела контрразведки армии, скрыл от сдачи в Госбанк СССР большое количество ценностей и валюты, изъятых в

33. Н. Н. Селивановский очень тяжело переживал свой арест. При этом следствию не удалось добиться каких либо важных показаний, он лишь признавал определенные служебные ошибки, да и то объяснял их «преступными указаниями» Абакумова. В конце концов, Селивановский обнаружил «затяжное реактивное состояние в форме психического параноида» и 2 января 1952 г. был направлен на стационарное психиатрическое исследование (ЦА ФСБ, ф. 4-ос., оп. 10, д. 1, л. 36).

34. Генерал-лейтенант Н. А. Королев пробыл в заключении до декабря 1953 г.

35. Полковник Я.Н. Матусов был уволен из МГБ еще в июле 1946 г., работал заведующим центральной юридической консультацией и сохранял дружеские связи с бывшими сослуживцами в МГБ. Реабилитирован и освобожден из заключения 5 июня 1953 г.

36. Он был освобожден «по амнистии» 21 ноября 1953 г., но не реабилитирован. Остались в силе обвинения в измене родине, вредительстве, антисоветской агитации и Т.П.

37. Осужден Особым совещанием при МГБ 23.08.52 г. на принудительное лечение. Вышел на свободу 15 мая 1954 г.

38. Осужден Особым совещанием при МГБ 02.07 .52 «за злоупотребление служебным положением, хищение государственного имущества и ложный донос» на 10 лет. Вышел на свободу 14.11 .58 г. инвалидом 3 группы. 
отделении Рейсбанка в Берлине, из которых часть присвоил, а некоторые ценности незаконно раздал своим подчиненным и другим лицам ${ }^{39}$.

Это были, пожалуй, отголоски арестов, проведенных еще в 1947-1948 гг., когда были взяты некоторые близкие к И. А. Серову руководящие работники аппарата НКВД-МГБ в Германии ${ }^{40}$. И, хотя о следствии против Зеленина и Карпенко Сталину докладывали одновременно с остальными делами арестованной верхушки абакумовского МГБ, все же они не были подверстаны к «заговорщикам», и их осудили довольно быстро, уже в 1952 г., да и без лишней огласки - во внесудебном порядке на Особом совещании при МГБ.

Но не все арестованные в этот период сотрудники МГБ оставались в ранге политзаключенных. Часть из них еще до смерти Сталина осудили за хозяйственные и другие уголовные преступления. Помимо упомянутого выше А. М. Палкина, осужденного 13 октября 1952 г. за хищения (что не помешало оставить его обвиняемым по делу Абакумова), это: П. С. Ильяшенко (арест 13 декабря 1951 г.) осужденный ОСО при МГБ к 10 годам 11 февраля 1953 г. также «за хищение социалистической собственности» ${ }^{41}$ и Г. М. Майрановский (арест 13 декабря 1951 г.), осужденный ОСО при МГБ 14 февраля 1953 г. на 10 лет «за незаконное хранение сильно действующих ядов и злоупотребления по службе»42. Также к февралю 1953 г. было закончено и передано на ОСО при МГБ дело бывшего старшего советника МГБ в Северной Корее Н. Н. Петрова (арестован в октябре 1951 г.).

Особняком стоит дело А. Т. Никифорова - начальника Тамбовского УМГБ, снятого с работы за злоупотребления по службе и написавшего анонимное клеветническое заявление. В октябре он был уволен из МГБ, в апреле 1952 г. исключен из партии, а 30 декабря 1952 г. Военная Коллегия Верховного Суда вынесла ему смехотворный приговор «за клевету» на полтора года лишения свободы ${ }^{43}$.

39. АП РФ, ф. 3, оп. 50, д. 185 , л. 68.

40. Тогда были арестованы генералы Г. А. Бежанов - начальник оперативного сектора НКВД-МГБ Тюрингии (арест 10.02.47 г.), С. А. Клепов - начальник оперативного сектора НКВД-МГБ Саксонии (арест 30.01 .48 г.) и А. М. Сиднев - начальник оперативного сектора НКВД-МГБ Берлина (арест 31.01.48 г.). Клепов и Бежанов были осуждены Военной коллегией Верховного Суда СССР 17.10.51 на 10 лет, а Сиднев по решению Особого совещания при МГБ 06.10.51 направлен на принудительное лечение. См. подробнее: Н. В. Петров, «Первый председатель КГБ генерал Иван Серов», Отечественная история, № 5, 1997, с. 32-34, 41.

41. Ильяшенко Павел Степанович, полковник, зам. нач. отдела МГБ (См.: АП РФ, ф. 3, оп. 24 , д. 480 , л. 153$)$.

42. Полковник медицинской службы Майрановский самая зловещая фигура сталинской госбезопасности. Именно он под руководством П. А. Судоплатова и Н. И. Эйтингона провел серию тайных убийств с помощью ядов курарина и рицина. Эти убийства были преподнесены как несчастные случаи. (См. о нем: Московские новости, 10 июня и 30 сентября 1990; 2 и 30 августа 1992; Известия, 16 мая 1992; В. Бобренев, В. Рязанцев, «Варсанофьевские призраки», Родина, № 11, 1995, с. 52-57.; В. Я. Бирштейн, «Эксперименты на людях в стенах НКВД», Человек, № 5, 1997, с. 114-132.

43. ЦА ФСБ, ф. 5-ос., оп. 2, д. 22, л. 244-245. 


\section{2. «Мингрельское дело»}

В ноябре 1951 г. разорвалась очередная бомба. Политбюро ЦК ВКП(б) приняло 9 ноября постановление «о взяточничестве в Грузии и об антипартийной группе т. Барамия». Несомненно, текст этого постановления был продиктован «знатоком» местной специфики Сталиным ${ }^{44}$. На смену законченному к тому времени «Ленинградскому делу» пришло «мингрельское дело». Для всесильного члена Политбюро ЦК, мингрела Л. П. Берии настала тревожная пора. В постановлении ЦК речь шла не только о мингрельском национализме, в нем содержались инвективы против грузинской эмиграции, якобы связанной с американской разведкой:

Грузинская эмиграция в Париже (Жордания-Гегечкори), как известно, обслуживает своей шпионской информацией о положении в Грузии американскую разведку, получая за это доллары. [...] шпионскоразведывательная организация Гегечкори состоит исключительно из мингрельцев. Следовательно, существует целая группа мингрельцев в Грузии, обслуживающих разведку Гегечкори ${ }^{45}$.

Упоминание в таком контексте Е. П. Гегечкори (брата жены Берии) было прямым выпадом против ближайшего сталинского соратника. Теперь, при желании, Сталин мог с легкостью растоптать Берию, имея явный козырь в виде постановления ЦК. И хотя в этом постановлении ничего не говорилось об арестах, они неизбежно последовали. Первым делом был арестован 2-й секретарь ЦК КП(б) Грузии М. И. Барамия ${ }^{46}$. Среди прочих ответственных советско-партийных работников Грузии были арестованы и многолетние сподвижники Берии, ранее работавшие под его руководством в НКВД: министр юстиции А. Н. Рапава (арестован в ноябре 1951 г.), профессор Тбилисского университета П. А. Шария (арестован 15 февраля 1952 г.), министр внутренних дел Г. Т. Каранадзе (арестован в 8 апреля 1952 г.), заместитель министра внутренних дел К. П. Бзиава (арестован 18 мая 1952 г.).

У истоков «мингрельского дела» стоял пришедший в 1948 г. на смену А. Н. Рапаве на должность министра ГБ Грузии Н. М. Рухадзе. Он был у Сталина в Цхалтубо на приеме 27 сентября 1951 г. и Сталин подробно

44. Ряд выражений в тексте постановлений недвусмысленно об этом свидетельствует, например пассаж о том, как Барамия, заступаясь за изгнанных из МГБ Грузии мингрельцев, «поскакал в Москву» и добился восстановления в аппарате госбезопасности «явно негодных работников». Кроме того Сталин собственноручно внес окончательную правку в текст документа. См.: Политбюро ЦК ВКП(б)..., указ. соч., c. 350 .

45. Там же, с. 351

46. В то время в грузинском руководстве шла вражда различных замляческих кланов. Инициатор «мингрельского дела» Н. М. Рухадзе не случайно нанес удар по группе во главе с Барамия, так как примерно в это же время эта группа требовала снятия Рухадзе с поста министра ГБ, обвиняя его в совершении уголовных преступлений (Политбюро $Ц К В К П(б) . .$, указ. соч., с. 356). 
расспрашивал его о грузинской эмиграции ${ }^{47}$. На этой встрече речь шла и о взяточничестве в Грузии, что тоже найдет отражение в тексте будущего постановления. Об этом можно судить по наброскам Сталина в своем блокноте, помеченным как «беседа с Рухадзе», где в частности записано: «нужен специальный орган в МГБ по поимке воров и взяточников из ответственных (верховных и средних) работников» ${ }^{48}$.

Рухадзе, вдохновленный Сталиным, решительно взялся за дело и готов был использовать любые методы. Но применение «физических методов воздействия» на арестованных требовало санкции вождя. Игнатьев 3 января 1952 г. вместе с Генеральным прокурором Г. Н. Сафоновым направил Сталину телеграмму военного прокурора Закавказского военного округа Лиховидова и министра ГБ Грузии Рухадзе, которые просили разрешить им «примененять репрессии (меры физического воздействия)» к арестованным по «Мингрельскому делу». При этом Игнатьев и Сафонов полагали, что делать это рано, а стоит продолжить активные допросы, и только потом, если подследственные не дадут «признательных показаний, следует рассмотреть вопрос о целесообразности применения к арестованным мер, предлагаемых т.т. Лиховидовым и Рухадзе» ${ }^{49}$. Для оказания помощи в МГБ Грузии из Москвы был направлен заместитель следственной части по особо важным делам МГБ В. Г. Цепков и с ним два «опытных следователя» ${ }^{0}$.

Вскоре Политбюро ЦК ВКП(б) вновь разбирало грузинский вопрос, на этот раз «о положении дел в компартии Грузии». Своим решением от 27 марта 1952 г. Политбюро сняло с должности первого секретаря ЦК КП(б) Грузии К.Н. Чарквиани, обвинив его в «политической слепоте» и «медлительности» в борьбе с «последствиями вражеской деятельности группы Барамия». Вместо Чарквиани первым секретарем было решено назначить А. И. Мгеладзе. Для проведения этого решения в жизнь в Грузию был направлен Л. П. Берия ${ }^{51}$. Ему предстояло выступить на пленуме ЦК КП(б) Грузии, рассказать о принятых в Москве решениях и обеспечить избрание нового грузинского руководства. Так решил сам Сталин ${ }^{52}$. В связи

47. ЦА ФСБ, ф. 4-ос., оп. 10, д. 73, л. 19-21. По другим источникам, эта встреча состоялась 26 сентября 1951 г. См.: К. А. Столяров, Палачи..., указ. соч., с. 173. Хотя не исключено что Сталин принимал Рухадзе дважды.

48. АП РФ, ф. 45 , оп. 1 , д. 22 , л. 7.

49. ЦА ФСБ, ф. 4-ос., оп. 10, д. 1, л. 54.

50. Там же.

51. Политбюро ЦК ВКП(б)..,, указ. соч., с. 352-354.

52. А. И. Мгеладзе, Сталин: Каким я его знал, [Б.М.], 2001, с. 192-195, 199. Согласно описанию Мгеладзе, в Кремль был вызван весь состав Бюро ЦК КП(б) Грузии для отчета о выполнении решения ЦК от 9 ноября 1951 г. На заседании председательствовал Маленков, также присутствовали Сталин, Берия, Молотов и Каганович. Берия выступил с резкими нападками на «мингрельцев», самокритично отметив при этом, что сам их рекомендовал на высокие должности. Было решено вместо К.Н. Чарквиани выбрать нового первого секретаря ЦК КП(б). Сталин поддержал кандидатуру Мгеладзе для избрания на этот пост. Вечером того же дня Мгеладзе был приглашен к Сталину на ужин, где присутствовали также Маленков и 
с этим неизбежно возникает вопрос : каковы были конечные цели Сталина в «мингрельском деле» и хотел ли он таким образом устранить Берию из руководства? Вероятнее всего, в задачи Сталина это не входило. «Мингрельское дело» возникло бы и без Берии. Его смысл заключался, прежде всего, в борьбе против клановости в грузинском руководстве. Конечно, в связи с этим делом Берия чувствовал себя крайне неуютно. Но цель Сталина была не уничтожить Берию (если захотел, то сделал бы это!), а держать в руках и время от времени напоминать, кто в стране «хозяин». Что же касается сталинского решения послать в Тбилиси именно Берию, то и это вполне в его духе. Будучи у Сталина на крючке, Берия не посмеет проявить хоть какое-то сочувствие мингрельцем, наоборот, будет к ним демонстративно жесток. Кроме того, Берия лучше других в Кремле знает обстановку в Грузии. Таким образом, никто лучше не сможет проводить там линию Сталина, чем Берия, боящийся зарекомендовать себя нелояльным или пристрастным. Зато теперь у Берии, по крайней мере, появился шанс взять развитие «мингрельского дела» под свой контроль.

Трудно сказать, удалось бы ему это, если бы ретивый Рухадзе сам не сделал роковой ошибки. Не умея вовремя остановиться, он стал добиваться у арестованных «мингрельцев» показаний на нового первого секретаря Мгеладзе и, добившись их, тут же направил материалы Сталину. Сталин 4 июня 1952 г. от имени ЦК ВКП(б) направил в Грузию телеграмму со строгим предупреждением Рухадзе «не допускать впредь подобных поступков» и предложением грузинам самим разобраться с Рухадзе. Сталина возмутило то, что Рухадзе в своей активности игнорировал ЦК и Правительство Грузии (в телеграмме напоминалось, что МГБ Грузии, «как союзно-республиканское Министерство, подчинено не только Центру, но и Правительству Грузии и ЦК КП(б) Грузии»), и то, что он «стал на неправильный и непартийный путь, привлекая арестованных в качестве свидетелей против партийных руководителей Грузии, особенно против тов. Мгеладзе»53. Теперь уж, вне всякого сомнения, Берия воспользовался ситуацией, и Рухадзе был снят с должности. Сначала такое решение приняли в Тбилиси на Бюро ЦК КП(б) Грузии (возможно, тут у Берии сохранялись рычаги), а 9 июня 1952 г. снятие Рухадзе было утверждено Сталиным и Политбюро ЦК ВКП(б) ${ }^{54}$. При назначении нового министра госбезопасности Грузии явно видна рука Берии. Первоначально хотели назначить его ближайшего соратника С. А. Гоглидзе, потом остановились на кандидатуре А. И. Кочлавашвили, тоже человеке бериевского круга ${ }^{55}$. Теперь дни Рухадзе были сочтены. Гоглидзе все же пришлось выехать в Тбилиси, но только для того, чтобы возглавить комиссию по приему-передаче дел МГБ Грузии. Ему

Берия. После ужина Сталин сообщил Мгеладзе, что в Тбилиси для разъяснения принятых решений и проведения кадровых перестановок поедет Берия.

53. Там же, с. 356

54. Там же, с. 357.

55. Там же. 
не терпелось арестовать Рухадзе, и Сталину пришлось остудить его пыл, 25 июня 1952 г. он написал в Тбилиси: «Вопрос об аресте Рухадзе считаем преждевременным», и предложил по окончании сдачи дел направить его в Москву «где и будет решен вопрос» 56.

Рухадзе был арестован 11 июля 1952 г. Чуть позднее был арестован его заместитель М. К. Тавдишвили ${ }^{57}$.

\section{3. Реорганизации в МГБ в 1952 г.}

В начале 1952 г. Сталин принял решение передать следствие по делу Абакумова и его группы из Прокуратуры в МГБ. Решение Политбюро об этом состоялось 12 февраля 1952 г. (П85/450). Прием дел поручался Рюмину. Решение обязывало Игнатьева «представить соображения о коренном улучшении следствия» в МГБ и устанавливало с 1 апреля 1952 г. срок ведения следствия по «наиболее важным» делам - 3 месяца, а для остальных дел -1 месяц $^{58}$. Этим же решением Политбюро вместо Л. Ф. Цанавы (отправленного «в распоряжение ЦК ВКП(б)») заместителем министра ГБ и начальником 2 главного управления был назначен В. С. Рясной.

Тогда же были предприняты серьезные попытки реорганизации структуры МГБ СССР. Уже 24 января 1952 г. Игнатьев, обращаясь к Поскребышеву, просил выслать ему постановление Политбюро ЦК ВКП(б) П51/4 от 4 мая 1946 «О структуре МГБ» с приложенной к нему схемой 59 . Это было явным свидетельством того, что разрабатывается новый вариант построения центрального аппарата МГБ.

11 июня 1952 г. Игнатьев обратился в Бюро Президиума Совета Министров СССР и сообщил, что в МГБ рассмотрели вопрос о сокращении численности работников центрального аппарата и местных органов и «в целях улучшения работы» сочли возможным сократить штаты на 15\%, то есть сократить 30 тысяч человек, что по словам Игнатьева, уменьшит расходы государства по МГБ на 450 миллионов рублей в год ${ }^{60}$. Видимо эти предложения Сталин счел недостаточно радикальными, и через несколько дней Игнатьев уже рапортовал о готовности сократить по системе МГБ

56. Там же, с. 357-358.

57. По некоторым сведениям бывший заместитель министра ГБ Грузии Тавдишвили был освобожден из заключения в октябре 1953 г. по амнистии.

58. Такие требования оказались невыполнимыми в условиях расследования следственной частью МГБ многочисленных дел. Вскоре, во изменение предыдущего решения, Политбюро 18 марта 1952 г. (П86/89) установило ввести эту норму с 1 июня 1952 г. См.: АП РФ, ф. 3, оп. 58, д. 10.

59. ЦА ФСБ, ф. 4-ос., оп. 10, д. 5. Письмо № 2216/И.

60. ЦА ФСБ, ф. 4-ос., оп. 10, д. 67, л. 175. 
35165 человек (17\% от общей численности) и в их числе 5187 человек «начальствующего состава» ${ }^{61}$.

Помимо чистки в МГБ, для Игнатьева важнейшим заданием Сталина оставалось - «вскрыть среди врачей вражескую группу». Но здесь ощутимых результатов он добиться так и не смог. В октябре 1951 г. он докладывал Сталину по телефону о ходе «дела врачей». Информация Игнатьева не удовлетворила вождя, и он выругал чекистов как «бездельников» 62 . Расследование этого надуманного дела действительно продвигалось слабо, сотрудники МГБ никак не могли доказать, а точнее сказать, создать доказательства связи «врачей-вредителей» с западными разведками. Сталин злился все больше и больше. В течение осени 1951 г. и января 1952 г. Игнатьев выслушал от него немало бранных слов и угроз: «Если не вскроете террористов, - американских агентов среди врачей, то будете там же где и Абакумов»... «Я не проситель у МГБ. Я могу и потребовать, и в морду дать, если вами не будут выполняться мои требования». И, наконец, потеряв терпение, грозил Игнатьеву и его сотрудникам: «Мы вас разгоним как баранов...» ${ }^{63}$. В один из воскресных дней августа 1952 г. Сталин окончательно вышел из себя. В очередной раз выслушав доклад Игнатьева о «деле врачей», он обозвал чекистов «бегемотами», заявив, что они «ожирели», «разучились работать», и подытожил: «старым работникам МГБ я не очень доверяю». Как позднее писал об этом эпизоде Игнатьев, он услышал из уст Сталина «матерную брань» ${ }^{64}$.

Многие арестованные высокопоставленные чекисты писали из заключения заявления на имя Сталина. Как правило, они признавали прежние «ошибки», а свою вину, чаще всего, сводили к тому, что, дескать попали под преступное влияние того или иного руководителя, или, скажем, «не разглядели» в своем руководстве врага и т. п. В общем, каждый старался свалить вину на другого и утопить кого-нибудь еще. А. Я. Свердлов, например, писал в августе 1952 г. Сталину, что он «проработав до 1940 г. под руководством Матусова, проводившего преступную практику, усвоил ряд пороков...» ${ }^{65}$. Ни разжалобить Сталина, ни убедить его в своей невиновности почти никому не удалось. Только Питовранов нашел верный тон и смог подобрать ключик к сердцу Сталина. Его письмо от 23 апреля 1952 г. (направленно Игнатьевым Сталину 19 мая) своеобразный пример проявления партийности и глубокой заботы о дальнейшем развитии и процветании советской разведки. Преамбула питоврановского письма оригинальна:

61. Там же, л. 182

62. ЦА ФСБ, ф. 5-ос., оп. 2, д. 31, л. 445-454.

63. Там же.

64. Там же.

65. Игнатьев 30 августа 1952 г. направил это письмо А. Н. Поскребышеву. (ЦА ФСБ, ф. 4-ос., оп. 10, д. 67, л. 191. 
После ареста первая мысль была, что со мной поступили слишком сурово, несправедливо. Но сразу же я дал себе отчет, что сколь скоро вопрос о моем аресте решился в ЦК, то думать о какой-то несправедливости было бы чудовищно, значило бы претендовать на то, что я умнее ЦК ${ }^{66}$.

Далее подкупая вождя искренностью, Питовранов писал, что теперь «пересмотрел всего себя, вывернул наизнанку и стал давать чистосердечные показания». Назвав Абакомова в письме «гадиной», Питовранов с горечью сетовал: «Я был молод, попал в обстановку восхваления Абакумова». После такого «правильного» вступления Питовранов переходит к делу и пишет свои соображения о делах МГБ. По его мнению, при кураторстве Секретаря ЦК А. А. Кузнецова административный отдел ЦК ВКП(б) был превращен в придаток МГБ, а его заведующий А. С. Бакакин ${ }^{67}$ «во всем слушал Абакумова». Питовранов писал:

Может быть Вы рассердитесь и скажите, что я лезу, куда мне теперь не следует, но я все же считаю необходимым для себя внести на Ваше рассмотрение несколько соображений по чекистской работе.

И вот тут в письме содержалось то, что Сталин не мог пропустить равнодушно. Питовранов предлагал полнее использовать как плацдарм разведки территорию Германии и Австрии, а сам аппарат разведки сделать «более гибким и оперативным».

В разведке много лет не было хороших руководителей. При т. Меркулове бездарный Фитин, при Абакумове - проходимец Кубаткин, а затем хоть и умный, но очень не оперативный и не острый Федотов. Я убежден, что т. Савченко тоже не тот человек, который должен возглавить разведку, чтобы она обеспечила выполнение требований ЦК.

Далее следовала самая важная часть - о «еврейских националистах»:

Все, что делалось по борьбе против еврейских националистов, которые представляют сейчас не меньшую, если не большую опасность, чем немецкая колония в СССР перед войной с Германией, сводилось к спорадическим усилиям против одиночек и локальных групп. Для того, чтобы эту борьбу сделать успешной, следовало бы МГБ СССР смело применить тот метод, о котором ВЫ упомянули, принимая нас, работников МГБ, летом 1951 г. ${ }^{68}$, а

66. АП РФ, ф. 3, оп. 58, д. 221, л. 1-12.

67. Точнее, А. С. Бакакин возглавлял отдел судебных и прокурорских органов в Управлении кадров ЦК ВКП(б) с 25.06.47 по 16.07.48.

68. Согласно журналу посещений Сталина в Кремле эта встреча состоялась 24 июля 1951 г. Присутствовали руководящие сотрудники МГБ: С. И. Огольцов, Н. К. Ковальчук, Н. Н. Селивановский, Е. П. Питовранов, С. А. Гоглидзе; также был на встрече С. Д. Игнатьев. Беседа Сталина с чекистами продолжалась всего 35 минут и проходила в присутствии Берии и Маленкова. См.: Исторический архив, № 1, 1997 , c. 24 . 
именно: создать в Москве, Ленинграде, на Украине (особенно в Одессе, Львове, Черновцах), в Белоруссии, Узбекистане (Самарканд, Ташкент), Молдавии, Хабаровском крае (учитывая Биробиджан), Литве и Латвии националистические группы из чекистской агентуры, легендируя в ряде случаев связь этих групп с зарубежными сионистскими кругами. Если не допускать шаблона и не спешить с арестами, то через эти группы можно основательно выявить еврейских националистов и в нужный момент нанести по ним удар. Начатая при тов. Игнатьеве такая работа по двум делам это подтверждает ${ }^{69}$.

Не забыл Питовранов написать и о Власике, предложив перестроить работу Главного управления охраны, отметив, что в его работе «много шумихи» и мало конспирации, - «о каждом шаге охраняемых знал в МГБ Абакумов». И в самом конце письма высказал свои соображения об усилении партийного влияния на органы госбезопасности:

Товарищ Сталин! ЦК ВКП(б) неоднократно отмечал, что врагам удавалось отрывать чекистские аппараты от партийных органов. Я думаю, что условие для этого отрыва в некоторой мере создается своеобразной кастовостью, флюсоподобной односторонностью многих чекистов, связанной в известной степени с особенностями их работы. Если Вами будет признано необходимым, я мог бы свои соображения по этому вопросу и предложения, вытекающие из них доложить т. Игнатьеву ${ }^{70}$.

Конечно, в конце письма содержалась и мольба: «Зная Вашу строгость, но и Ваше великодушие, я как родного отца прошу Вас, товарищ Сталин дать мне возможность исправиться» ${ }^{71}$.

Сталин давно присматривался к ведомству Власика. И вряд ли является совпадением тот факт, что Игнатьев, задержав у себя письмо Питовранова почти на месяц, направил его Сталину 19 мая 1952 г. - в тот же день, когда было принято постановление Политбюро (П87/358) «О сокращении расходов по Управлению охраны». В постановлении говорилось об «антигосударственной практике в расходовании средств» и о «преступном расточительстве». ГУО МГБ потеряло статус главного управления и стало просто «Управлением охраны». Его руководитель Н. С. Власик был снят с должности начальника и отправлен в систему МВД заведовать лагерем на Урале, и еще 6 руководящих работников ГУО этим же постановлением были сняты со своих должностей и отправлены на работу в систему МВД (они получили должности заместителей начальников различных лагерей). Руководить охраной кремлевских вождей временно поручили самому министру ГБ Игнатьеву ${ }^{72}$. Этим дело не ограничилось. В мае 1952 г.

69. АП РФ, ф. 3 , оп. 58 , д. 221, л. 1-12.

70. Там же, л. 12.

71. Там же, л. 8.

72. Решение Политбюро ЦК ВКП(б) от 19 мая 1952 г. «особая папка». АП РФ, ф. 3, оп. 58 , д. 10. 
арестовали работников охраны МГБ В. С. Лынько и Б. М. Кошелева ${ }^{73}$. Продолжились аресты и среди других категорий чекистов. В мае 1952 г. был арестован бывший работник разведки МГБ А. А. Гузовский ${ }^{74}$.

Нашло отклик и еще одно обращение «снизу». Как только Сталин получил письмо двух работников разведки А. М. Голицына ${ }^{75}$ и Е. Г. Кащеева, в котором содержались критические замечания о работе разведки МГБ, он мог вспомнить и о предложениях Питовранова. Уже в ночь с 4 на 5 октября 1952 г. Сталин принял обоих офицеров в Кремле. При их беседе длившейся 1 час 40 минут присутствовал только Берия ${ }^{76}$. На свое счастье Питовранов вновь напомнил о себе, и 17 октября 1952 г. его очередное письмо из секретариата Сталина Поскребышевым было направлено (надо полагать после того как его прочел Сталин) Маленкову. Кажется, дело Питовранова сдвинулось с мертвой точки. Уже в начале ноября 1952 г. он был освобожден из тюрьмы и, отдохнув несколько дней, 13 ноября 1952 г. был принят Сталиным в Кремле ${ }^{77}$.

События двух последних месяцев 1952 г. Гоглидзе описывал так ${ }^{78}$. В первых числах ноября 1952 г. Игнатьев, Рясной, Гоглидзе и Рюмин были вызваны к Сталину в кабинет в связи с заявлением работников разведки Кащеева и Голицына, и Сталин поручил подготовить предложения о реорганизации разведывательной и контрразведывательной служб МГБ79. Через неделю была сформирована Комиссия по реорганизации структуры МГБ ${ }^{80}$ и 19 ноября был подготовлен и представлен Сталину проект структуры Главного разведывательного управления (ГРУ) МГБ, в котором объединялись 1 и 2 главные управления МГБ - соответственно, разведка и контрразведка ${ }^{81}$.

Между тем произошло еще одно знаменательное событие. Решением Сталина, оформленном как постановление Совета Министров СССР 13 ноября 1952 г., Рюмин был снят с должности заместителя министра ГБ и

73. Заместитель Главного управления охраны (ГУО) МГБ СССР полковник В. С. Лынько был арестован 10 мая 1952 г., осужден ОСО при МГБ 4 октября 1952 г. на 10 лет за преступную халатность. Освобожден в апреле 1953 г. из Владимирской тюрьмы. Б. М. Кошелев - майор интендантской службы до ареста занимал должность начальника 2 отдела хозяйственного управления ГУО МГБ СССР.

74. Гузовский находился в заключении до августа 1954 г.

75. Занятно, что заботу о делах разведки проявлял будущий перебежчик. В 1961 г. из резидентуры КГБ в Хельсинки Голицын бежал на Запад.

76. Исторический архив, № 1, 1997, с. 32.

77. Там же, с. 33.

78. Объяснительная записка Гоглидзе о «деле врачей» от 26 марта 1953 г. См.: ЦА ФСБ, ф. 4-ос., оп. 11, д. 1, л. 315-322.

79. Это произошло 3 ноября 1952 г. Беседа длилась 1 час 45 минут. Помимо Сталина на беседе присутствовал и Маленков. Исторический архив, № 16, 1997, с. 33.

80. Бюро Президиума ЦК КПСС 9 ноября создало Комиссию по реорганизации разведывательной и контрразведывательной служб в МГБ. Возглавил комиссию Маленков. См. Источник, № 5, 2001, с. 130.

81. ЦА ФСБ, ф. 4-ос., оп. 10, д. 69. 
начальника следственной части по ОВД МГБ за то, что «не добрался до корней дела» и «не способен выполнить» указания Правительства по расследованию дел Абакумова - Шварцмана и «врачей», которые «все еще остаются нераскрытыми до конца» ${ }^{82}$. И в этот же день Сталин в своем кабинете имел серьезную беседу с Игнатьевым, Гоглидзе, Огольцовым, Рясным и Питоврановым, в ходе которой дал указания по дальнейшему ведению следствия по делам «врачей» и Абакумова с его сообщниками ${ }^{83}$. Аудиенция длилась 40 минут и, кроме приглашенных работников МГБ, присутствовали члены «узкого руководства» Булганин, Берия, Маленков и Хрущев ${ }^{84}$. Именно они были выбраны стареющим вождем в качестве преемников. После ХІХ съезда КПСС между ними, разумеется по воле Сталина, и была разделена власть.

События ноября 1952 г. заставили Игнатьева немало поволноваться, и он серьезно заболел ${ }^{85}$. После 15 ноября 1952 г. мы не видим подписи Игнатьева на текущих документах, идущих «наверх»-Сталину и в ЦК (это делают Гоглидзе и Огольцов).

20 ноября Сталин вызвал к себе в кабинет Огольцова, Питовранова и Гоглидзе для рассмотрения представленного ими проекта об организации Главного разведывательного управления (ГРУ) МГБ. «Обсуждение представленного проекта, - вспоминал Гоглидзе ${ }^{86}$, проходило в крайне острой, накаленной обстановке. На нас обрушился целый ряд обвинений, носящий политический характер». Основное недовольство Сталина было вызвано «отказом» МГБ от применения в борьбе с противником методов диверсий и террора, тем что «проморгали» врагов в стране. При этом Сталин сослался на дела врачей и Абакумова, а под конец приема пообещал устроить чекистам «всенародную чистку» от «вельмож», «бездельников» и «перерожденцев». В этот же день было решено назначить Огольцова и

82. АП РФ, ф. 3, оп. 58, д. 10, л. 159

83. Игнатьев, в своем письме Сталину от 15 ноября 1952 г. впрямую ссылается на выполнение им сталинских директив, полученных 5 и 13 ноября. «Во исполнение Ваших указаний», - писал Игнатьев, - Абакумов переведен из Лефортовской тюрьмы в Бутырскую и содержится в ручных кандалах, а к арестованным врачам Егорову, Виноградову и Василенко «применены меры физического воздействия», также «подобраны и уже использованы в деле два работника, могущие выполнять специальные задания (применять физические наказания) в отношении особо важных и особо опасных преступников», и, далее Игнатьев сообщал, что вызвал Власика в Москву для того, чтобы расспросить его о враче Егорове и «преступном отношении врачей к лечению руководящих работников». (АП РФ, ф. 3, оп. 58, д. 10, л. 160-161).

84. Исторический архив, № 1, 1997, с. 33.

85. Игнатьев писал позднее в объяснительной записке: « 15 ноября я серьезно заболел» (ЦА ФСБ, ф. 5-ос., оп. 2, д. 31, л. 445-454).

86. ЦА ФСБ, ф. 4-ос., оп. 11, д. 1, л. 315-322. 
Гоглидзе первыми заместителями министра ГБ ${ }^{87}$ и курирование следственной части по ОВД возложить на Гоглидзе ${ }^{88}$.

29 ноября 1952 г. Гоглидзе подготовил для Сталина докладную записку «о положении дел в МГБ» ${ }^{89}$. За время, прошедшее после принятия постановления партии от 11 июля 1951 г., говорилось в докладной, «требуемого улучшения работы органов государственной безопасности не произошло». Далее Гоглидзе расписался в полном бессилии МГБ разобраться со следственными делами, так волновавшими Сталина. Следствие по «делу врачей велось крайне медленно», - писал он, - «До сих пор ни агентурным, ни следственным путем не вскрыто, чья злодейская рука направляла террористическую деятельность Егорова, Виноградова и других» ${ }^{90}$. Также, писал Гоглидзе, «не лучше обстоит с делом о вредительской работе Абакумова - Шварцмана. Следствие по этому делу так же не добилось полной ясности», а «следователи работают без души» ${ }^{91}$ Что это означало, Гоглидзе пояснил так: «следователи не цепляются, как крючки, за каждую даже мелкую возможность, чтобы поймать, взять в свои руки врага - полностью его разоблачить» ${ }^{92}$. Касаясь общих проблем работы МГБ, Гоглидзе отметил, что имело место «грубое извращение» в организации разведывательной работы, выразившееся в отказе от «активных, наступательных средств борьбы с противником за границей - осуществлении диверсионных и террористических операций», и, тут же, отметил «недопустимую разобщенность» 1 (разведывательного) и 2 (контрразведывательного) главков МГБ (здесь само, собой напрашивался вывод о необходимости их объединения). Также Гоглидзе писал, что «коренная перестройка агентурно-оперативной работы», и требования Постановления СМ СССР от 7 января 1952 г. (и приказов МГБ № 0015 и 0022) «выполнены формально» ${ }^{93}$. Гоглидзе привел внушительные цифры освобожденных от «руководящей работы» чекистов за период с 1 июля 1951 г. по 1 июля 1952 г. За год было освобождено «как не справившихся с работой» 1583 человека (в их числе 287 работников входящих в номенклатуру ЦК КПСС), уволено из органов за «нарушение дисциплины», «советской законности», «злоупотребление служебным положением», «морально-бытовое разложение» - свыше 3000 человек (из них 500 работников центрального аппарата). По указанию ЦК, - писал далее Гоглидзе, - в сентябре 1952 г. были сокращены штаты МГБ на 31641

87. Решением Бюро Президиума ЦК КПСС 20 ноября 1952 г. «О заместителях министра госбезопасности» (БП3/116).

88. После отстранения 13 ноября 1952 г. М. Д. Рюмина, следственную часть по ОВД МГБ временно возглавил Соколов (был исполняющим обязанности).

89. ЦА ФСБ, ф. 4-ос., оп. 10, д. 68, л. 130-141.

90. Там же, л. 131.

91. Там же, л. 132.

92. Там же.

93. Там же, л. 136. 
человека, но «несмотря на это, в органах МГБ осталось еще немало лиц, недостойных работать в ЧК» ${ }^{94}$. Последняя фраза должна была продемонстрировать Сталину готовность руководства МГБ к проведению дальнейшей чистки. Тут же писалось и о намеченных мероприятиях для исправления положения: обновление состава следственной части по ОВД МГБ, улучшение работы по «приобретению» (то есть новым вербовкам) и «воспитанию» агентуры, проведение «в ближайшее время» совещания руководящего состава МГБ, направление на работу в МГБ новых кадров из партийных органов и т.п. По видимому, этот вариант доклада был обсужден верхушкой МГБ и, после незначительных исправлений, через день, 30 ноября 1952 г. за подписями Игнатьева, Гоглидзе и Огольцова был отослан Сталину ${ }^{95}$.

На следующий день, 1 декабря состоялось заседание Президиума ЦК КПСС, на котором рассматривались вопросы: «О вредительстве в лечебном деле» и «Информация о положении дел в МГБ СССР» и обсуждалось письмо МГБ от 30 ноября 1952 г. Для разработки проектов резолюций по этим вопросам была создана Комиссия под председательством Маленкова. Проекты резолюций следовало подготовить уже к 4 декабря ${ }^{96}$. Резолюция «О положении в МГБ» была одобрена решением Президиума ЦК КПСС 4 декабря 1952 г. В тексте резолюции содержался призыв усилить контроль партийных органов за работой МГБ, и, в частности говорилось, что «первые секретари обкомов, крайкомов партии и ЦК компартий союзных республик обязаны интересоваться агентурной работой органов МГБ и им должен быть известен список всех агентов» ${ }^{97}$. В резолюции, помимо общих призывов перейти от «пассивной» оборонной тактики к «активным наступательным действиям» в разведывательной работе, содержался и гневный пассаж, несомненно, продиктованный Сталиным:

Многие чекисты прикрываются при этом гнилыми и вредными рассуждениями о якобы несовместимости с марксизмом-ленинизмом диверсий и террора против классовых врагов. Эти горе-чекисты скатились с позиций революционного марксизма-ленинизма на позиции буржуазного либерализма и пацифизма, забыли, что с озверевшим классовым врагом нельзя бороться в белых перчатках, оставаться «чистенькими», не применяя активных наступательных средств борьбы в интересах социалистического государства, забыли указания Ленина о том, что классовая борьба - это жестокая борьба, а не пустая болтовня, не понимают той простой истины, что нельзя МГБ представлять без диверсий, проводимых им в лагере врага ${ }^{98}$.

\footnotetext{
94. Там же, л. 139.

95. Там же, л. 142

96. АП РФ, ф. 3 , оп. 58 , д. 10 , л. 163

97. Там же, д. 10, л. 185.

98. Там же.
} 
Примерно ту же мысль Сталин повторил и на заседании комиссии по организации ГРУ МГБ. Возможно, это произошло 15 декабря 1952 г. ${ }^{99}$. Здесь прозвучали некоторые тезисы из письма Питовранова: «Главный наш враг - Америка. Но основной упор надо делать не собственно на Америку, первая база, где нужно иметь своих людей, - Западная Германия» ${ }^{100}$. И тут же Сталин вернулся к волновавшей его теме: «Коммунистов, косо смотрящих на разведку, на работу ЧК, боящихся запачкаться, надо бросать головой в колодец» 101.

В первые месяцы 1953 г. в недрах МГБ готовились новые структура и штаты Главного управления разведки МГБ и схемы реорганизации службы наружного наблюдения. Сам приказ о слиянии 1 и 2 главных управлений МГБ был выпущен 5 января за № $006^{102}$. Но в его подкрепление требовалось утвердить структуру и штат и провести в ЦК утверждение кандидатур начальников отделов входящих в ГРУ. Для рассмотрения всех вопросов по организации ГРУ МГБ в ЦК КПСС была образована комиссия ${ }^{103}$. Регулярно из МГБ в эту комиссию поступали все новые и новые варианты штатов и структуры ГРУ и службы наружного наблюдения (бывшее 7 управление), но до самой смерти Сталина окончательного решения ЦК КПСС по этим вопросам не приняли.

99. 15 декабря 1952 г. Сталин принял в Кремле руководителей МГБ Игнатьева, Огольцова, Гоглидзе, Рясного и Питовранова. При этом присутствовали только члень Комиссии по организации ГРУ МГБ: Г. М. Маленков, Л. П. Берия, Н. С. Хрущев, Н. А. Булганин, Н. А. Михайлов, Л. И. Брежнев и А. Б. Аристов. Беседа длилась 1 час 5 минут. См.: Исторический архив, № 1, 1997, с. 34.

100. Эти замечания Сталина опубликованы в журнале Источник, № 5, 2001, с. 132.

101. Эта мысль оказалась созвучной настроениям последователей Сталина. Фраза настолько понравилась председателю КГБ Ю. В. Андропову, что когда в 1973 г. в архиве обнаружился листок с записью «замечаний Сталина», он немедленно отослал экземпляр Брежневу, напомнив ему о работе в комиссии Президиума ЦК, сопроводив сталинский текст своим замечанием: «Лично мне очень импонирует его высказывание... Мысль, по форме маленько азиатская, но по существу, верная даже в пору далекую от времен культа личности». Вообще замечания Сталина Андропов посчитал не только «вполне актуальными и сегодня», но и «пригодными во все времена». Брежнев тоже проникся важностью и значимостью сталинских мыслей о разведке и с пометой «важный документ» отложил его в папку для подготовки к апрельскому (1973) пленуму ЦК КПСС обсуждавшему вопросы международной деятельности ЦК КПСС. См.: Источник, № 5, 2001, с. 130-131, 149

102. Начальником ГРУ МГБ был назначен С. И. Огольцов, а его заместителями Е. П. Питовранов (он же начальник 1 управления ГРУ МГБ - по разведке) и В. С. Рясной (он же начальник 2 управления ГРУ МГБ - по контрразведке). Приказ был выпущен на основе решения Бюро Президиума ЦК КПСС БП7/12-оп от 30 декабря 1952 г. См.: Лубянка. Справочник, сост. А. И. Кокурин, Н. В. Петров, научн. редактор Р. Г. Пихоя, М., 1997, с. 40. Также см.: А. И. Кокурин, Н. В. Петров, «МГБ: структура, функции, кадры», Свободная мысль, № 11, 1997, с. 119

103. Решением Президиума ЦК КПСС П3/115 от 20 ноября 1952 г. в состав комиссии вошли: Г. М. Маленков (председатель), Л. П. Берия, Н. С. Хрущев, Н. А. Булганин, Н. Г. Игнатов, Н. А. Михайлов, Л. И. Брежнев, А. Б. Аристов, С. Д. Игнатьев, С. А. Гоглидзе, С. И. Огольцов, Е. П. Питовранов, В. С. Рясной. «На основании указаний ЦК» комиссии поручалось наметить структуру ГРУ и определить задачи. Срок работы был дан 7 дней. Позднее в комиссии появился Н. М. Пегов. 
Кадровая чистка в МГБ продолжалась и имела явный национальный оттенок. Так, 6 января 1953 г. Гоглидзе письмом доложил Сталину, что «рассмотрены материалы на лиц еврейской национальности» находящихся на руководящей работе в органах военной контрразведки. При этом были представлены краткие справки на 21 человека. Как сообщал Гоглидзе, принято решение всех их уволить и принять меры к трудоустройству в другие учреждения. Далее отмечалось, что в периферийных органах контрразведки на оперативно-технической работе остается еще 123 человека. МГБ, писал Гоглидзе, затребовало на каждого из них материалы для решения вопроса о их дальнейшей работе в МГБ ${ }^{104}$.

27 января 1953 г. «неожиданно» выздоровел Игнатьев и проинформировал Сталина, что он приступил к работе после болезни и просил разрешение созвать 14 февраля 1953 г. совещание ответственных работников МГБ. Выдержанное в возвышенном тоне письмо Игнатьева должно было убедить Сталина, что Постановление ЦК КПСС от 4 декабря 1952 г. «О положении в МГБ» понято им правильно и принято к неукоснительному исполнению:

\begin{abstract}
Вместе с парторганизациями и членами коллегии мы сосредоточиваем все свое внимание и усилия на том, чтобы, на основе решений ЦК и Ваших указаний, в короткий срок навести порядок в работе органов МГБ, повысить их активность, покончить с благодушием, ротозейством, трусостью и укоренившимися среди многих работников привычками жить былой славой чекистских органов без затраты труда и времени на повседневную черновую работу по охране безопасности нашего государства в настоящее время. Выполняя Ваши, товарищ Сталин, указания, мы будем настойчиво продолжать работу по выявлению и ликвидации американо-английских и иных шпионов, террористов и диверсантов из числа врачей, еврейских националистов и других врагов нашей партии и Советского государства ${ }^{105}$.
\end{abstract}

Многие фразы этого письма поразительно напоминают произнесенное в разные годы Сталиным. Тут есть и прямые перепевы мотивов 1937 г. Только вместо «троцкистско-бухаринских и иных двурушников» теперь на первый план вышли «американо-английские и иные шпионы».

В конце 1952 г. и самом начале 1953 г. аресты руководящих сотрудников МГБ продолжились. Теперь жертвами стали чекисты, ранее охранявшие Сталина. Бывший начальник Главного управления охраны (ГУО) МГБ СССР Н. С. Власик был арестован 16 декабря 1952 г., об этом сообщил Сталину Гоглидзе ${ }^{106}$. Так же 17 января был арестован С. Ф. Кузьмичев ${ }^{107}$

104. К письму были приложены списки евреев - сотрудников военной контрразведки. (ЦА ФСБ, ф. 4-ос., оп. 11, д. 30, л. 1).

105. Там же, д. 30, л. 225.

106. «Приступили к его допросам», - писал Гоглидзе. (ЦА ФСБ, ф. 4-ос., оп. 10, д. 68, л. 192.) Основанием для ареста Власика послужили показания арестованных работников Главного управления охраны МГБ В. С. Лынько и Б. М. Кошелева. См.: ЦА ФСБ, ф. 4-ос., оп. 11, д. 12, л. 31-33. 
«как пособник шпионской деятельности Федосеева И. И.»108. А 2 февраля 1953 г. Игнатьев обратился к Маленкову, Берии и Булганину с просьбой дать санкцию на арест бывшего начальника оперативного отдела ГУО МГБ В. И. Масленникова за то, что он «преступно относился к сигналам о неправильном лечении руководителей Партии и Правительства» ${ }^{109}$. Через пару дней, 5 февраля 1953 г. Масленников был арестован ${ }^{110}$.

Также проявились и некоторые последствия «Ленинградского дела», хотя тут просьбы на санкционирование арестов шли на имя Г. М. Маленкова. 26 ноября 1952 г. Гоглидзе направил ему справку на бывшего начальника УМВД по Ленинградской области генерал-майора в отставке Е.С. Лагуткина, исключенного из партии еще в 1950 г. за «антипартийные действия», а теперь, как писал Гоглидзе, установлено, что он имел «близкие связи» с А. А. Кузнецовым и другими ленинградцами ${ }^{111}$.

16 февраля 1953 г. Игнатьев доложил Сталину о проведенных в этом месяце арестах еще 4-х евреев - бывших чекистов, к тому времени уже уволенных из МГБ. Это - И. И. Илюшин-Эдельман, И. Э. Фридман, Г. М. Чайковский и И. Е. Фастовский ${ }^{112}$.

В начале 1953 г. был подготовлен проект обвинительного заключения по делу Абакумова, и 17 февраля Игнатьев направил его Сталину и Маленкову. Определился круг обвиняемых «по группе бывших работников МГБ». Речь шла о «вражеской группе Абакумова - Шварцмана». Кроме них по делу обвинялись: Л. Ф. Райхман, А. Г. Леонов, М. Т. Лихачев, В. И. Комаров, И. А. Чернов, Я. М. Броверман, А. Я. Свердлов и А. М. Палкин - всего 10 человек. Игнатьев предложил рассмотреть дело в Военной Коллегии Верховного Суда и приговорить всех к расстрелу ${ }^{113}$. В отношении остальных

107. С 1932 по 1947 С. Ф. Кузьмичев служил в личной охране Сталина, был к 1947 г. генерал-майором, начальников Управления охраны № 1. С 1947 г. на учебе в Высшей школе МГБ, затем работал уполномоченным СМ СССР по курортам Сочи-Мацеста, с ноября 1949 г. возглавил Управление охраны № 2 МГБ СССР, а с августа 1950 г. стал заместителем начальника УМГБ Брянской области. См.: АП РФ, ф. 3, оп. 24, д. 474, л. $37-38$

108. И. И. Федосеев провинился в том, что работая заместителем коменданта «ближней дачи», устраивал в отсутствии Сталина там пьянки, воруя продукты и вино из дачных запасов, и привозил из Москвы на дачу проституток, которые заглядывали в «совершенно секретные» документы на столе вождя. В 1947 г. по распоряжению Сталина Федосеев был «тайно» арестован и расследование вел Серов. При этом Сталин просил Кузьмичева не говорить об этом аресте Абакумову, но Кузьмичев, все же рассказал Абакумову. В апреле 1950 г. Федосеев был расстрелян. А Сталин, видимо, узнал о «неверности» Кузьмичева много позже, и это стало главным мотивом ареста. О деле Федосеева см. подробнее: Н. В. Петров, «Первый председатель КГБ генерал Иван Серов», Отечественная история, № 5, 1997, с. 33-34.

109. ЦА ФСБ, ф. 4-ос., оп. 11, д. 30, л. 293-294.

110. Освобожден из-под стражи с полным прекращением дела и реабилитацией 18 апреля 1953 г. по постановлению следственной части по ОВД МВД СССР.

111. ЦА ФСБ, ф. 4-ос., оп. 10, д. 54, л. 384-391.

112. ЦА ФСБ, ф. 4-ос., оп. 11, д. 31, л. 138-140.

113. Там же, л. 141-180. 
арестованных работников МГБ Игнатьев сообщил, что ведутся отдельные дела и по ним «дано указание следствие закончить» и продолжать его лишь в отношении М. И. Белкина в связи с произведенными по его показаниям арестами в Венгрии ${ }^{114}$. Ознакомившись с представленным Игнатьевым проектом Сталин написал на полях первого листа: «Не мало?», по видимому, имея ввиду круг обвиняемых. Помимо того, Сталину был представлен список «бывших работников МГБ арестованных в связи с решением ЦК КПСС “о неблагополучном положении в МГБ”», чьи дела будут заканчиваться отдельно от дела Абакумова-Шварцмана. В списке значились: Н. Н. Селивановский, Н. А. Королев, Г. В. Утехин, М. И. Белкин, Н. И. Эйтингон, В. М. Блиндерман (бывший начальник отдела «Р» МГБ), Е. С. Анцелиович (бывший заместитель начальника отдела «Р» МГБ), М. К. Кочегаров (бывший начальник управления делами МГБ), Л. Е. Иткин (бывший заместитель начальника следственного отдела УКР СМЕРШ Московского военного округа) и И. М. Кузнецов (бывший начальник личной охраны Абакумова) $)^{115}$.

Вскоре, для обсуждения обвинительного заключения, Сталин вызвал к себе министра ГБ С. Д. Игнатьева, его заместителя С. А. Гоглидзе, заместителей начальника следственной части МГБ Н. М. Коняхина и В. Н. Зайчикова. Позднее об этом писал в своем заявлении в ЦК КПСС Зайчиков. По его воспоминаниям, Сталин «подверг представленный ему проект обвинительного заключения критике главным образом за то, что документ неубедительно показывал причины и процесс падения Абакумова» ${ }^{116}$. Сталин призвал чекистов написать в обвинительном заключении «всю правду об этом, какой бы она не была». Любопытно, что в этом разговоре Сталин якобы возложил всю вину на Берию за выдвижение Абакумова на столь высокий руководящий пост. По словам Зайчикова, он заявил буквально следующее:

У нас кандидатура Абакумова не вызывала доверия. Назначили мы его по настоянию Берия. Вскоре после назначения членам Политбюро стало ясно, что Абакумов не на месте. Вот из-за такого отношения к подбору кадров я недолюбливаю Берия и не доверяю ему ${ }^{117}$.

Конечно, Сталин либо хитрил, либо уже сам себя убедил, что выдвинул Абакумова в мае 1946 г. на пост министра не он, а кто-то другой. Все же вероятнее всего хитрил, пытаясь создать у работников МГБ впечатление собственной объективности и непричастности к делу.

114. Там же.

115. Там же, л. 181 .

116. Заявление В. Н.Зайчикова в ЦК КПС от 16 июля 1953 г. см.: АП РФ, ф. 3, оп. 24, д. 481, л. 42-43.

117. Там же. 
Между тем тучи, сгустившиеся в конце 1951 г. над Берией, постепенно рассеивались. Арестованный Рухадзе на допросе 2 февраля 1953 г. (протокол этого допроса был послан Сталину) заявил:

Я признаю, что отдельными своими действиями по существу компрометировал Л. П. Берия, в частности, я приказал установить технику [имеется ввиду техника прослушивания - Н.П.] на квартиру у матери Л. П. Берия проживающей в гор. Тбилиси... ${ }^{118}$.

Незадолго до этого произошло очередное возвышение Берии, 26 января 1953 г. на заседании Бюро Президиума ЦК КПСС он был назначен руководителем «тройки» по наблюдению за «специальными работами». Кроме Берии в «тройку» вошли Маленков и Булганин ${ }^{119}$. Теперь в руках Берии сосредоточилось все руководство советским военно-промышленным комплексом, тогда как ранее он координировал лишь атомный проект.

Сталин подверг серьезной правке проект обвинительного заключения по делу Абакумова - Шварцмана. Общая направленность сталинской редактуры свелась к подчеркиванию персональной вины Абакумова, заключавшейся в том, что он и его сообщники «игнорировали указания ЦК КПСС о расследовании связей с иностранной разведкой врага народа Кузнецова» ${ }^{120}$. То есть погасили шпионскую составляющую «Ленинградского дела».

Переработанный с учетом замечаний Сталина проект обвинительного заключения по делу Абакумова - Шварцмана вновь был направлен 26 февраля 1953 г. Сталину и Маленкову. Теперь к прежним 10 обвиняемым добавился М. К. Кочегаров - бывший начальник управления делами МГБ. Документ был составлен Н. М. Коняхиным. Его подписали следователи, ведшие дело: помощники начальника следственной части по ОВД МГБ В. Н. Зайчиков и П. И. Гришаев. Визу: «Согласен» проставил отвечавший за следствие С. А. Гоглидзе и, наконец, утвердил заключение сам министр С. Д. Игнатьев ${ }^{121}$.

Сталин не успел рассмотреть этот проект.

События, 1951-1953 гг., удивительным образом перекликаются с 1937 г., когда после резолюции февральско-мартовского пленума ЦК ВКП(б) начались регулярные аресты руководителей НКВД. Обвинения, выдвинутые против руководства МГБ, практически идентичны тем, что выдвигались еще в 1937 г. Это ведомственная замкнутость системы госбезопасности, «обман» партийных органов и ЦК, наличие не разоблаченных врагов и неэффективная работа, засоренность кадрового состава чуждыми и подозрительными людьми. Вновь зазвучала и оценка Сталина, высказанная им еще в мае 1937 г. на узкой встрече с чекистами: «нас разбили в разведке»,

118. ЦА ФСБ, ф. 4-ос., оп. 11, д. 31, л. 52.

119. Политбюро ЦК ВКП(б).., указ. соч., с. 101.

120. Р. Г. Пихоя, указ. соч., с. 73.

121. ЦА ФСБ, ф. 4-ос., оп. 11, д. 31, л. 214-252. 
из чего следовал вывод, что страна наводнена иностранными шпионами (эта же мысль присутствует и в письме Рюмина). Все это неизбежно вело к инициированию Сталиным нового этапа чистки не только МГБ, но и всего общества. Методы «лечения» системы МГБ Сталин избрал вполне традиционные. Это, прежде всего, кадровая перетряска в сочетании с арестами высокопоставленных сотрудников, усиление партийного влияния за счет рекрутирования руководящих сотрудников МГБ из недр партийного аппарата, установление строгого контроля за работой местных МГБ со стороны партийных руководителей. Ситуация, как ее рассматривал Сталин, была весьма серьезной. Видимо события 1952 г. следует считать прологом нового террора, хотя и в ином, модифицированном виде (с целенаправленными ударами по определенным слоям и национальным группам). Именно в этом году Сталин (как и в 1937) впервые после войны не поехал в отпуск, а остался в Москве. Мало кто обратил внимание на юбилейную статью в Правде посвященную 15-летию доклада Сталина на февральско-мартовском пленуме ЦК ВКП(б) ${ }^{122}$, а ведь этот доклад с 1937 г. ни разу не переиздавался ${ }^{123}$. Такая актуализация зловещего доклада кое-что значила. Но несомненно и то, что никаких планов действительно массовых арестов (как в 1937-1938 гг.) у Сталина не было. Скорее можно говорить о его новой линии «рационализации» террора. По крайней мере, на это были направлены все сталинские усилия по повышению эффективности работы МГБ: сокращение кадрового состава, перестройка его структуры, наконец, существенное сокращение аппарата тайных агентов и ликвидация института осведомителей. Об этом же свидетельствует и общее сокращение (почти в три раза) проведенных МГБ в 1952 г. арестов по сравнению с 1951 г.

\section{4. Деятельность Берии: реабилитация и новые аресты}

После смерти Сталина, в условиях развернувшейся в Президиуме ЦК борьбе за власть, Берия выступил инициатором пересмотра наиболее громких дел возникших в конце 40-х начале 50-х годов. Прекращая дела, Берия убивал сразу нескольких зайцев. Во-первых, он оказывал вполне дружеские услуги своим соратникам: Маленкову (интересы которого были задеты делом 1946 г. о вредительстве в авиационной промышленности), Молотову (чья жена была арестована Сталиным в связи с делом ЕАК), Кагановичу (чей брат Михаил был оклеветан и покончил с собой) ${ }^{124}$. Во-вторых, прекращая «мингрельское дело» Берия по сути устранял угрозу собственной персоне ${ }^{125}$.

122. Н. Михайлов, «Выдающийся документ большевизма», Правда, 5 марта 1952.

123. Как это ни странно, переиздание будет осуществлено «Политиздатом» уже после смерти Сталина в 1954 г.

124. Лаврентий Берия. 1953. Стенограмма июльского пленума ЦК КПСС и другие документы, под ред. акад. А. Н. Яковлева; сост. В. Наумов, Ю. Сигачев, М., 1999, с. 19, 25-28, 42 .

125. Там же, с. $37-42$. 
В третьих, освобождая из тюрьмы соратников-чекистов, получал в их лице надежных и преданных сотрудников. И, наконец, легко зарабатывал авторитет и политический капитал, выгодно выставив себя поборником справедливости. Последнее обстоятельство больше всего и разозлило остальных членов Президиума ЦК КПСС. К осознанию необходимости пересмотра сфальсифицированных в бывшем МГБ дел советские лидеры были психологически подготовлены. Как позднее заявил на пленуме ЦК Н. А. Булганин, они еще «при жизни товарища Сталина» между собой говорили о том, что эти дела «дутые» ${ }^{126}$. Но то, что Берия начатую реабилитацию запишет в заслугу только себе, их не устраивала. Позднее его обвинили в том, что он преподнес результаты реабилитации врачей «сенсационно, бурно, искусственно» ${ }^{127}$, хотя обнародовать правду о «деле врачей» советскому правительству пришлось вовсе не по прихоти Берии. Об аресте «врачей-вредителей» в январе 1953 г. было объявлено на всю страну $^{128}$ и в газетах развернулась шумная пропагандистская кампания по повышению бдительности. Но, не смотря на разоблачение «заговора» кремлевских врачей, «первый пациент» все же умер. Народная молва тут же напрямую связала смерть Сталина с происками «врачей-убийц» 129 . Продолжение «дела врачей» могло бросить тень «соучастия» на ближайших сталинских соратников. Это обстоятельство и потребовало от нового руководства не только прекратить дело, но и объясниться с народом.

Первым же желанием Берии после смерти вождя было освобождение своих людей - чекистов. Уже 11 марта 1953 г. он направил на имя Маленкова и Хрущева письмо, в котором рисовал удручающую картину сложившуюся в МГБ. Берия писал: «Значительная часть чекистских кадров имеющих опыт - разгромлены», причем разгром кадров был проведен в 2 этапа - 1-й при Абакумове, 2-й после его ареста. «Необходимо будет рассмотреть материал на арестованных чекистов и в зависимости от результатов принять решение об использовании их на работе в МГБ» ${ }^{130}$. С помощью этого письма Берия готовил почву не только для освобождения из тюрем своих людей, но и для пополнения нового объединенного МВД старыми проверенными кадрами. И не случайно речь в письме идет о первом этапе «разгрома кадров», под которым Берия имел ввиду увольнение в 19461947 гг. его ставленников из МГБ: В. Н. Меркулова, Б. З. Кобулова, С. Р. Мильштейна, Л. Е. Влодзимирского и других. Многих из них он вернул в 1953 г. под свое крыло в МВД. Кстати, в этом же письме, касаясь структуры организуемого под его началом министерства, Берия предлагает убрать

126. Там же, с. 113.

127. Реабилитация: как это было. Документы Президиума ЦК КПСС и другие материалы, сост. А. Н. Артизов, Ю. В. Сигачев, В. Г. Хлопов, И. Н. Шевчук, т. 1, М., 2000 , c. 383.

128. Правда, 13 января 1953.

129. Неизвестная Россия. ХХ век. Книга вторая, М., 1992, с. 254.

130. ЦА ФСБ, ф. 4-ос., оп. 11, д. 1, л. 394. 
ГУЛАГ из МВД, объясняя этот шаг необходимостью «освобождения от несвойственных функций» ${ }^{131}$.

Берия не медлил и начал освобождать своих соратников еще до формального разрешения вопроса на Президиуме ЦК КПСС. Так были освобождены: С. Ф. Кузьмичев (10 марта 1953), П. А. Шария (март 1953)132, Н. И. Эйтингон (19 марта 1953) $)^{133}$, Г. В. Утехин (21 марта 1953), Ф. Г. Шубняков (март 1953). Затем настала очередь других: Г. Т. Каранадзе (10 апреля 1953), К. П. Бзиава (10 апреля 1953), А. Н. Рапава (10 апреля 1953 г.), В. И. Масленников (18 апреля 1953 г.). В апреле 1953 г. были освобождены: Л. Ф. Райхман и В. С. Лынько, а в мае - Ш. С. Шлюгер ${ }^{134}$. Чуть позднее были освобождены: М. И. Белкин (4 июня 1953 г.); Я. Н. Матусов (5 июня 1953 г.). Также вышли на свободу Н. Н. Селивановский и А. Я. Свердлов.

Разумеется, милость нового всесильного министра внутренних дел не распространялась на тех, кто участвовал в гонениях на близких Берии людей или кого он считал человеком абакумовского круга. Так, остались под арестом: В. С. Абакумов, Н. М. Рухадзе, Н. С. Власик, Н. А. Королев, М. К. Кочегаров $^{135}$, А. Г. Леонов, М. Т. Лихачев, В. И. Комаров, И. А. Чернов, Я. М. Броверман, Л. Л. Шварцман.

В марте - начале апреля 1953 г. к ним добавились и новые арестованные, кого Берия причислил к виновникам позднесталинского произвола: М. Д. Рюмин, В. Г. Цепков, Л. Ф. Цанава, С. И. Огольцов ${ }^{136}$.

Можно предположить, что Абакумов до своего ареста вовсе не числился врагом Берии. По крайней мере, об этом есть ряд свидетельств. Несмотря на то, что Сталин лично курировал работу МГБ, Абакумов часто обращался и

131. Там же.

132. Берия освободил из тюрьмы П. А. Шария одним из первых. Обстоятельства этого освобождения описал в своем рапорте 24 августа 1953 г. бывший помощник начальника следственной части А. А. Болховитин: «Друг Берия - Шария был, например, освобожден по одному окрику Берия на бывшего начальника внутренней тюрьмы МВД СССР А.Н. Миронова за несколько дней до вынесения постановления об освобождении...». (АП РФ, ф. 3, оп. 24, д. 467, л. 102).

133. Заступив на пост министра Берия сразу же поинтересовался где находится Н. И. Эйтингон и узнав, что он болен язвой желудка и лежит в тюремной больнице, послал Гоглидзе навестить его (разумеется с хорошей новостью о предстоящем освобождении). По указанию Берии П. Я. Мешик и В. В. Иванов прекратили дело и реабилитировали Эйтингона 19 марта 1953 г., а также Берия распорядился выплатить ему 35 тысяч рублей. (АП РФ, ф. 3, оп. 24, д. 466, л. 167-169).

134. Как и многие другие чекисты, в ходе сталинской чистки МГБ Шлюгер был арестован за «националистические высказывания».

135. Кочегаров был осужден Военной Коллегией Верховного Суда СССР 20 января 1954 г. на 10 лет «за расхищение государственных средств и материальных ценностей». Правда к нему применили Указ об амнистии 1953 г., сократив ему срок до 5 лет, а 6 декабря 1954 г. и вовсе освободили. (ГАРФ, ф. 8131, оп. 32, д. 4575, л. 135-136).

136. С. И. Огольцов и Л. Ф. Цанава оказались в заключении по решению Президиума ЦК КПСС от 3 апреля 1953 г. за организацию убийства С. Михоэлса в 1948 г. Огольцова в августе 1953 г. выпустили, тогда как Цанава не только остался сидеть, но и был переведен в разряд бериевцев. (См.: Реабилитация: как это было.., указ. соч., с. 383.) 
советовался с Берией. Кроме того, как утверждал начальник 5 управления МГБ А. П. Волков, Абакумов «перед Берия заискивал, тогда как с Сусловым и Пономаренко был груб» ${ }^{137}$. По заявлению того же Волкова, Абакумов «оберегал Цанаву», который отличался «редким самодурством и отвратительным барством», а также «злобным преследованием “непокорных" работников»138. Бывший министр Абакумов оставался крупной фигурой, и его судьбу мог решить только Президиум ЦК КПСС; единоличного решения Берии тут было недостаточно. Да и сам Берия, вероятно, не собирался хлопотать за него. Видно не мог ему простить уволенных из МГБ в 1946-1947 гг. Меркулова, Кобулова, Мильштейна и Влодзимирского.

Почему Берия не освободил из-под стражи Власика, которого он без сомнения хорошо знал, тоже более или менее понятно. Осенью 1945 г. Сталин, будучи на отдыхе и обдумывая планы смены руководителей НКВД и НКГБ (Берии и Меркулова), расспрашивал Власика о других руководящих чекистах. По словам Власика:

Глава Правительства, находясь на Юге после войны, в моем присутствии выражал большое возмущение против Берия, говоря о том, что органы государственной безопасности не оправдали своей работой должного обеспечения. Указал на отдельные провалы в работе его руководства и сказал, что дал указание отстранить Берия от руководства в НКВД. Спрашивал меня, как работал Меркулов, Кобулов, и впоследствии о Гоглидзе и Цанаве. Я рассказал ему, что знал, с теми фактами, которые мне были известны по работе о недостатках руководства ${ }^{139}$.

По видимому, Берия догадался о роли Власика в событиях конца 1945 начала 1946 гг., когда он и ряд его людей (В. Н. Меркулов, Б. З. Кобулов и другие) были отстранены от руководства НКВД и НКГБ. И вот весной 1953 г. Берия и Кобулов вызвали Власика на допрос, после которого ему стало ясно, что Берия все знает о том давнем разговоре со Сталиным. Теперь, как вспоминал Власик, он понял, что «кроме смерти», ему «ждать больше нечего» ${ }^{140}$. Но после ареста Берии надежда у него появилась. Тем не менее, новое руководство страны не выпустило его из тюрьмы, предъявив обвинения в «злоупотреблении доверием», «разбазаривании средств», а также в том, что в 1945 г. Власик будучи в Потсдаме, вывез из Германии трофейное имущество для себя и несколько голов скота и две лошади для

137. АП РФ, ф. 3, оп. 24, д. 467, л. 15.

138. В этом же заявлении от 21 августа 1953 г. Волков писал, что Цанава «спекулирует на родстве с Берия». См.: Там же, л. 15.

139. Заявление Н. С. Власика на имя К. Е. Ворошилова от 8 апреля 1955 г. См.: Свободная мысль, № 11, 2001, с. 108-109.

140. Там же, с. 109. 
родственников $^{141}$. Эти обвинения по сравнению с предыдущими выглядели сущим пустяком, и Власик отделался сравнительно мягким приговором ${ }^{142}$.

Прекратив «мингрельское дело» и выпустив арестованных (в их числе П. А. Шария, А. Н. Рапава, К. П. Бзиава и Г. Т. Каранадзе), Берия направил в ЦК КПСС записку143 для партийной реабилитации пострадавших. Редактирование этой записки Берия поручил Шарии - одному из недавних арестантов $^{144}$. Президиум ЦК КПСС рассмотрел записку Берии на заседании 10 апреля 1953 г. и вынес решение об отмене предыдущих, принятых при Сталине постановлений о «мингрельской националистической группе» и о выселении из Грузии «враждебных элементов» ${ }^{145}$.

Большинство выдвиженцев из партийных органов, пришедших на работу в центральный аппарат МГБ в 1951-1952 гг., при перетряске кадров в марте - апреле 1953 г. были уволены или вытеснены на периферию. О принципах своей кадровой политики Берия довольно откровенно заявил начальнику управления кадров МВД Б. П. Обручникову в апреле 1953 г., когда тот принес список пришедших в МГБ при Игнатьеве руководящих сотрудников и предложил их оставить на работе в центральном аппарате МВД. Обручников описал реакцию министра так:

Берия меня буквально разнес и приказал выгнать всех на периферию, как игнатьевцев, и сказал, что в аппарат нужно подбирать старых работников, уволенных из органов, которых, как он заявил, «я знаю» ${ }^{146}$.

Не менее бурной была и сцена, когда выполняя указание Берии подготовить назначения руководителей объединенных управлений МВД на местах, Обручников, прежде всего, составил бумаги для утверждения их кандидатур в ЦК КПСС:

Когда я явился к Берия с проектом представления в ЦК КПСС, он меня выругал площадной бранью и заявил, что ему не нужно никаких представлений, а нужен приказ. Когда я ему добавил, что вопрос о

141. ЦА ФСБ, ф. 4-ос., оп. 11, д. 12, л. 31-33.

142. Н. С. Власик 17 января 1955 г. был осужден к ссылке на 10 лет, а уже в мае 1956 г. помилован. Подробнее об обвинениях и суде над ним см.: В. М. Логинов, Тени Сталина, М., 2000, с. 142-162.

143. Записка № 24/Б от 8 апреля 1953 г. опубликована: Лаврентий Берия. 1953.., указ. соч., c. $29-37$.

144. Позднее на следствии Берия подтвердил факт участия Шария в работе над запиской в ЦК. На вопрос следователя: «Где это видно, чтоб арестованный по своему же делу составляет справку в ЦК партии?», Берия заявил: «это моя ошибка, его не нужно было привлекать для этого». (АП РФ, ф. 3 , оп. 24, д. 465, л. 88)

145. См.: Лавренитий Берия. 1953..., указ. соч., с. 37-40.

146. АП РФ, ф. 3 , оп. 24, д. 464, л. 75. 
кандидатурах не согласован с секретарями обкомов, Берия буквально рассвирепел и выгнал меня из кабинета ${ }^{147}$.

Получивших свободу Л. Ф. Райхмана, Н. И. Эйтингона, С. Ф. Кузьмичева, Берия назначил на высокие посты в аппарате МВД. Но этот факт сыграл с ними злую шутку. После падения Берии они вновь были арестованы. Так, С. Ф. Кузьмичев, которого сразу после освобождения Берия назначил начальником Управления охраны МВД, был вторично арестован 3 июля 1953 г. В отличие от остальных бериевцев Кузьмичеву повезло и он был освобожден из под стражи и реабилитирован решением Президиума ЦК КПСС 3 февраля 1954 г. ${ }^{148}$. Эйтингон и Райхман остались в тюрьме и оба были осуждены в середине 50-х за «преступления против КПСС». Весной 1953 г. членов Президиума ЦК неприятно поразила расторопность Берии при освобождении своих знакомых чекистов. Об этом с возмущением говорил Хрущев:

Вот был арестован Кузьмичев. Я думаю, что его освободить нужно было, но нужно ли было этого Кузьмичева, освобождая из тюрьмы, сразу одеть в генеральский костюм и назначить начальником охраны членов Президиума ЦК $?^{149}$

Вызвав арестованного С. Ф. Кузьмичева Берия ему напрямик заявил «Твое дело - чепуха. Тебя приказал посадить Сталин» ${ }^{150}$. И другим намеченным к освобождению арестованным чекистам Берия заявлял примерно тоже. Это стало позднее одним из пунктов обвинения уже против самого Берии. Идти на пересмотр дел сталинского МГБ члены Президиума ЦК были готовы, но вслух признать персональную ответственность Сталина за беззакония и, более того, разделить эту ответственность, это было уж слишком! В приватных высказываниях Берии его соратники по Президиуму ЦК усмотрели «клевету на Сталина и советский строй», и этот пункт позднее был даже включен в обвинительное заключение по делу Берии. Тут уместно вспомнить вполне партийную позицию Питовранова, так подкупившую Сталина и имевшую результатом его освобождение. Питовранов прямо писал, что его посадили правильно, так как это было сделано по решению ЦК, а ЦК никогда не ошибается. Хрущев и Маленков еще не отделяли Сталина от партии, и высказывания Берии рассматривали как выпады против ЦК КПСС.

Комментируя надуманность ряда дел против чекистов, затеянных по инициативе Сталина, Берия заявлял в своем кругу: «Сталин и Гоглидзе хотел

147. По утверждению Обручникова при этом в кабинете Берии присутствовали также С. С. Мамулов, В. П. Доброхотов, Б. З. Кобулов, С. Н. Круглов и И. А. Серов. (АП РФ, ф. 3 , оп. 24 , д. 467, л. 74$)$.

148. АП РФ, ф. 3 , оп. 24, д. 474, л. 36.

149. Лаврентий Берия. 1953..., указ. соч., с. 90-91.

150. АП РФ, ф. 3, оп. 24, д. 470, л. 96. 
посадить» ${ }^{151}$. Отчасти это и объясняет, почему Берия сохранил и в 1953 г. рядом с собой Гоглидзе, убрав подальше других заместителей бывшего министра Игнатьева. При этом ближайших людей своего заместителя Серова, осужденных ранее за злоупотребления в Германии, Берия освобождать из тюрьмы и реабилитировать не торопился. Возможно, зря, а то бы накануне грозных для себя событий заручился поддержкой человека, тесно связанного с Хрущевым. После ареста Берии за них активно похлопотал Серов, и довольно быстро их освободили: Г. А. Бежанова 23 июля и А. М. Сиднева - 27 июля 1953 г. В том же 1953 г. вышел на свободу и С. А. Клепов. Мотивы у Серова были те же что и у Берии, когда он торопился прекратить опасное и неудобное для него «мингрельское дело». Ведь начальники оперативных секторов НКВД земель в Германии Клепов, Бежанов и Сиднев совершили свои преступления под руководством Серова, который сам уцелел чудом - Сталин проявил милость и не наказал.

Берия был арестован «соратниками» 26 июня 1953 г. прямо на заседании Президиума ЦК КПСС. Вслед за этим последовали аресты людей его круга. О масштабах арестов по делу Берии можно судить по записке прокурора Руденко направленной в ЦК КПСС 12 октября 1953 г. (Маленкову и Хрущеву), где говорилось о близком окончании дела, в котором в числе обвиняемых кроме самого Берии значились Меркулов, Кобулов, Гоглидзе. Влодзимирский и Мешик: «Кроме того, - писал Руденко, - арестованы и привлечены к уголовной ответственности еще 44 соучастника Берии, дела которых выделены в отдельные производства» 152 .

С этого момента главным обвиняемым стал Берия. Все внимание членов Президиума ЦК КПСС было сосредоточено на его деле. И именно расследование дела Берии придало новый и мощный импульс процессу реабилитации. Речь шла уже о пересмотре не только единичных дел, но и целых категорий, например, осужденных внесудебными органами. В этих условиях «дело Абакумова - Шварцмана» временно ушло на второй план. Да и сами обвинения, ранее выдвинутые против Абакумова, «морально устарели». Всерьез к его делу вернулись весной 1954 г., после реабилитации пострадавших по «Ленинградскому делу». Теперь вина Абакумова заключалась в проведении незаконных репрессий и его задним числом причислили к «банде Берия» ${ }^{153}$.

Научно-информационный и просветительский Центр «Мемориал»

Малый Каретный пер., 12

103051 Москва

memnipc@glasnet.ru

151. АП РФ, ф. 3, оп. 24, д. 472, л. 103

152. АП РФ, ф. 3, оп. 24, д. 471, л. 49-50.

153. О судах над чекистами после смерти Сталина см.: Звенья: Исторический альманах, вып. 1, М., 1991, с. 430-436. 